2. To: (Receiving organization)
Storage and Disposal

5. Proj prog 10 ept $/$ Div.:

Org. Code 73510

8. Originator Renarks: comments dispositioned. Final review and approval

requested. Provide any significant comments to R. B. Calmus via cc:mail by the required response date.

11. Receiver Renarks:
3. From: (originating Organization)
Disposal Engineering

6. cog. Engr.:

R. B. Calmus
This document has been reviewed by WHC and DOE-RL staff and

4. Related EDT No.:

N/A

7. Purchase order No.:

$\mathrm{N} / \mathrm{A}$

9. Equip./Component Mo.:

$N / A$

10. System/8ldg./Facility:

N/A

12. Major Assm. Dwg. No.:

$N / A$

13. Permit/Permit Application Mo.: N/A

14. Required Response Date:

May 14, 1996

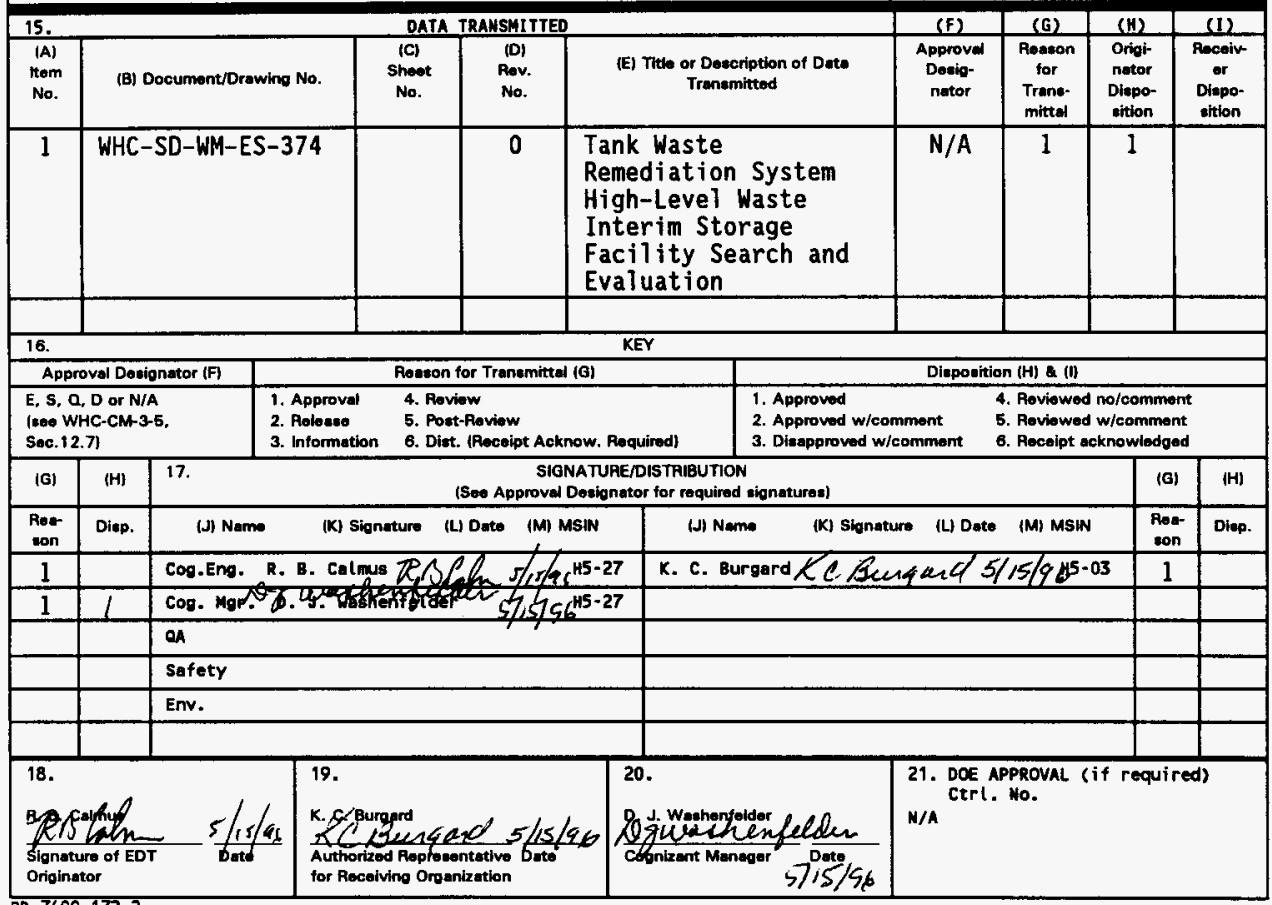

BD-7400-172-2

(04/94) GEF097 


\section{INSTRUCTIONS FOR COMPLETION OF THE ENGINEERING DATA TRANSMITTAL}

(USE BLACK INK OR TYPE)

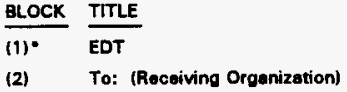
(A) * Item Number
(B) * Document/Drawing No.
(C) * Sheet No.
(D) Rev. No.
(E) Title or Description of Data Tronamitted
(F) * Impact Level
(G) Reason for Transmittel
(H) Originator Disposition
(I) Receiver Disposition

(18) Koy

(17) Signature/Distribution
(G) Reason
(H) Disposition
(J) Name
(K) * Signature
(L) * Date
(M) * MSIN

(18) Signeture of EDT Originator

(19) Authorized Ropresentative for Receiving Organization

(20)* Cognizant Mansgar

(21)* DOE Approvel
- Pro-assigned EDT number.

- Enter the individual's neme, title of the organization, or entity (e.g., Distribution) that the EDT is being transmitted to.

- Enter the title of the orgenization originating and transmitting the EDT.

- Enter EDT numbers which relate to the data being transmitted.

- Enter the Project/Progrem/Department/Division title or Project/Progrem acronym or Project Number, Work Order Number or Organization Code.

- Enter the neme of the individuel identified as being responeible for coordinating diepoaition of the EDT.

- Enter related Purchase Order (P.O.) Number, if aveileble.

- Enter special or additional comments concerning transmittel, or "Koy" retrievel words may be entered.

- Enter equipment/component number of affected item, if appropriate.

- Enter eppropriate system, building or facility number, if appropriato.

- Enter special or edditionel comments concerning tranemittel.

- Enter applicable drawing number of major ascembly, if eppropriate.

- Enter applicable permit or permit application number, if appropriate.

- Enter the date a respones is required from individuals identified in Block 17 (Signature/Distribution).

- Enter sequentiel number, beginning with 1, of the information listed on EDT.

- Enter the unique identification number assigned to the document or drawing being tranamitted.

- Enter the shoet number of the information being transmitted. If no shoot number, leave blank.

- Enter the revision number of the information being tranemitted. If no revieion number, leove blank.

- Enter the title of the document or drawing or a briof description of the subject if no title is identified.

- Enter the appropriate Impact Level (Block 15). Also, indicate the eppropriate approvale for acch item listed, i.e., SQ, ESQ, otc. Use NA for non-encineering documente.

- Enter the eppropriate code to identity the purpose of the date transmittal (see Block 16).

- Enter the eppropriate diaposition code (8ee Block 16).

- Enter the eppropriate diaposition codo (see Block 16).

- Number codes ueed in completion of Blocks 15 (G), (H), and (I), and 17 (G), (H) (Signaturo/Distribution).

- Enter the code of the reason for tranamittal (Block 16).

- Enter the code for the disposition (Block 16).

- Enter the signature of the individuel completing the Disposition 17 (H) and the Transmittel.

- Obtein appropriate signature(a).

- Enter date signature is obteined.

- Enter MSIN. Note: If Distribution Sheat is used, show antire distribution fineludine that indicated on Page 1 of the EDT) on the Distribution Sheot.

- Enter the signeture and date of the individuel originating the EDT contered prior to trenemittal to Receiving Organization). If the EDT originator is the cognizant ongineer, sign both Blocks 17 and 18 .

- Enter the signature and dote of the individuel identified by the Receiving Organization as suthorized to approve disposition of the EDT and acceptance of the date tranamitted, as epplicable.

- Enter the signeture and date of the cognizent manager. (This signature is authorization for roloase.)

- Enter DOE approval (if required) by letter number and indicate DOE oction.

"Asteriak denote the required minimum items check by Configuration Documentation prior to relese; these are the minimum rolese requirements. 


\title{
TWRS HLW Interim Storage Facility Search and Evaluation
}

\author{
R. B. Calmus
}

Westinghouse Hanford Company, Richland, WA 99352

U.S. Department of Energy Contract DE-AC06-87RL10930

EDT/ECN: 607723

Org Code: 73510

UC: UC-2000

B\&R Code: EW3130010

Charge Code: D4NBl

Total Pages: 65

Key Words: HLW, Interim Storage, Facility Search

Abstract: The purpose of this study was to identify and provide an evaluation of interim storage facilities and potential facility locations for the vitrified high-level waste (HLW) from the Phase I demonstration plant and Phase II production plant. In addition, interim storage facilities for solidified separated radionuclides (Cesium and Technetium) generated during pretreatment of Phase I Low-Level Waste Vitrification Plant feed was evaluated.

TRADEMARK DISCLAIMER. Reference here in to any specific comercial product, process, or service by trade neme, tredenark, manufacturer, or otherwise, does not necessarily constitute or imply its endorsement, recomnendation, or favoring by the United States Government or any agency thereof or its contractors or subcontractors.

Printed in the United States of America. To obtain copies of this document contact: WHC/BCS Document Control Services, P.O. Box 1970, Mailstop H6-08, Fax (509) 376-4989.
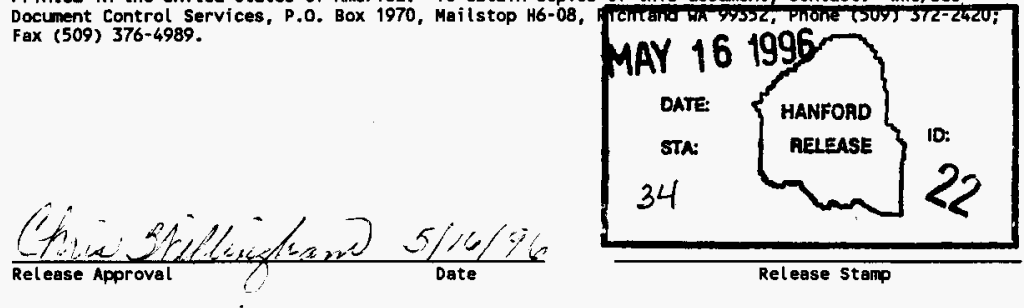

Approved for Public Release 


\section{EXECUTIVE SUMMARY}

This Letter Report evaluates the alternatives available for storage of vitrified high-level waste (HLW) glass canisters produced during the Tank Waste Remediation System privatization Phase I and Phase II work scope.

The evaluation was made by reviewing previous reports and engineering studies that examined existing site facilities and new facilities for use as storage locations for $\mathrm{N}$ Reactor fuel and HLW. These documents were examined to determine (1) if the facilities meet criteria established for interim storage of HLW canisters, (2) the estimated cost for modifications to existing facilities, and (3) the options available for new facilities.

Based on the criteria for a storage facility, separate alternatives were identified for Phase I and Phase II. The Canister Storage Building, currently being constructed to hold the spent nuclear fuel from the $\mathrm{K}$ Basins, is the preferred choice for the Phase I HLW glass canisters. The Canister Storage Building meets all the criteria, has the lowest cost for modifications, and can be expanded if required.

The preferred choice for the Phase II HLW glass canisters is a new storage facility. A vault storage-type facility has the lowest estimated cost, but further studies should be done to determine which storage method best satisfies Phase II requirements. 
WHC-SD-WM-ES-374

Revision 0

This page intentionally left blank. 
WHC-SD-WM-ES-374

Revision 0

\section{CONTENTS}

1.0 INTRODUCTION . . . . . . . . . . . . . . . . . . . 1-1

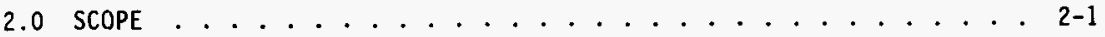

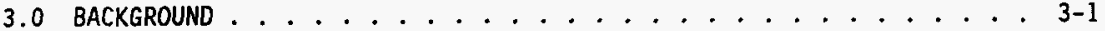

4.0 CRITERIA . . . . . . . . . . . . . . . . . . . 4-1

5.0 ANALYSIS . . . . . . . . . . . . . . . . . . . . 5-1

5.1 CANYON BUILDINGS .......................... 5-1

5.1 .1 B Plant .................... . . 5-1

5.1.2 T Plant .................... 5-1

5.1 .3 U Plant ................... 5-1

5.1 .4 PUREX ..................... 5-2

5.2 FMEF . . . . . . . . . . . . . . . . . . 5-8

5.3 WNP-1 AND WNP-4 SPRAY PONDS ................ . . 5-10

5.4 CSB FOR PHASE I AND PHASE II HLW . . . . . . . . . . . . . 5-20

5.5 NEW FACILITY FOR PHASE I STORAGE . . . . . . . . . . . 5-22

5.5.1 Standalone Casks................ . 5-22

5.5 .2 Housing Arrays . . . . . . . . . . . . . . . . . . 5-30

5.5.3 Vault Storage .................. 5-36

5.6 OFFSITE . . . . . . . . . . . . . . . . . . . . 5-40

5.7 PHASE II STORAGE ................. . . . . . . . . . . . . .

6.0 SUMMARY . . . . . . . . . . . . . . . . . . . . . 6-1

7.0 REFERENCES . . . . . . . . . . . . . . . . . . . . . 7-1

8.0 BIBLIOGRAPHY . . . . . . . . . . . . . . . . . . 8-1 
WHC-SD-WM-ES-374

Revision 0

\section{LIST OF FIGURES}

3-1 Tank Waste Remediation System Privatization Phase I Alternative Site Locations ................... 3-3

3-2 Tank Waste Remediation System Privatization Phase I Recommended Area . . . . . . . . . . . . . . . . . . 3-5

5-1 Multicanister Storage Rack. . . . . . . . . . . . . . 5-4

5-2 Canister Storage Facility for 221-U Building Canyon Area. . . . . . 5-5

5-3 Canister Storage Facility for 202-A Building (Plutonium-Uranium Extraction) Canyon Area Section .......... 5-7

5-4 Plan View Below Operating Deck ............... 5-11

5-5 Plan View Above Operating Deck .............. 5-13

5-6 Longitudinal Section Looking North . . . . . . . . . . . . . 5-15

5-7 Transverse Section Looking East . . . . . . . . . . . . 5-17

5-8 Illustration of Typical NUHOMS Storage Module Arrangement . . . . . 5-32

5-9 NUHOMS System Components, Structures, and Transfer Equipment . . . . 5-33

5-10 NUHOMS Horizontal Storage Module Arrangement . . . . . . . . . 5-34

5-11 Single MVDS Vault Module . . . . . . . . . . . . . . . 5-37

5-12 MVDS Natural Convection Cooling - Vault Cross-Section . . . . . 5-39

\section{LIST OF TABLES}

5-1 Storage System Parameters for Phase I Canisters . . . . . . . 5-29

5-2 Storage System Parameters For Phase II Canisters . . . . . . . . 5-41

6-1 Compliance with Design Criteria ............ 6-2 


\section{TANK WASTE REMEDIATION SYSTEM HIGH-LEYEL MASTE} INTERIM STORAGE FACILITY SEARCH AND EVALUATION

\subsection{INTRODUCTION}

The U.S. Department of Energy (DOE) has embarked upon a course to privatize the immobilization of high-level waste (HLW) at the Hanford Site. The $p$ lan is for the DOE to pay for the immobilized HLW after it is produced. The plan contains a two-phased approach. Phase I will demonstrate "proof-ofprinciple" and show the viability and capability to process the HLW fraction of the tank waste using a small-scale HLW vitrification plant. This will provide confidence in proceeding with a full-scale plant which is Phase II of the privatization mission.

This report identifies and provides a preliminary evaluation of interim storage facilities for the immobilized HLW from the Phase I Demonstration Plant and Phase II Production Plant. This report also evaluates storage of secondary HLW products (i.e., solidified and canisterized cesium) generated during pretreatment of Phase I low-level waste (LLW) vitrification plant feed. 
WHC-SD-WM-ES-374

Revision 0

This page intentionally left blank. 
WHC-SD-WM-ES-374

Revision 0

\subsection{SCOPE}

The study identifies facilities that can be used for interim storage of the Phase I and Phase II HLW canisters and Phase I-generated cesium canisters. This study was accomplished by reviewing reports of previous studies that have examined similar issues at the Hanford Site.

Options evaluated in this study are as follows: modification of existing canyon facilities, modification of the Spent Nuclear Fuel (SNF) Canister

Storage Building (CSB), construction of a new facility, and offsite storage.

The new facility and offsite storage options are analyzed based on capabilities for storing Phase I and Phase II waste. 
WHC-SD-WM-ES-374

Revision 0

This page intentionally left blank. 
WHC-SD-WM-ES-374

Revision 0

\subsection{BACKGROUND}

The Phase I HLW portion of double-shell tank waste will be processed into an immobilized product based on the DOE-issued Request for Proposal (RL 1996). For purposes of this study, it is assumed the waste form will be a

borosilicate glass which will be poured into metal canisters $3 \mathrm{~m}$ long and $0.61 \mathrm{~m}$ in diameter. It is also assumed that the Phase I Demonstration Plant will produce approximately 1 MT/day of HLW glass product for 5 to 9 years. A facility for interim storage of the Phase I canisters must be provided. The estimated number of Phase I immobilized glass canisters is 1,140 .

Vitrified HLW processed in Phase II will consist of the remaining HLW. The current reference Phase II canister will be longer than the Phase I canister. The dimensions of the Phase II canister are $0.61 \mathrm{~m}$ outer diameter by $4.57 \mathrm{~m}$ long. The estimated number of Phase II canisters ranges from 6,000 to 20,000 .

Interim storage of secondary HLW and solidified cesium is also evaluated in this report. This waste will be produced from the pretreatment of LLW to separate out the HLW fraction for immobilization. The cesium will be in the form of a dry ion-exchange resin.

Proposed locations for the Phase I and Phase II waste treatment processing facilities were identified in a report issued in January 1996 (Shord 1996). Four alternative sites were considered, and are within, or adjacent to, the 200 East Area in the vicinity of the AP Tank Farm (Figure 3-1). The recommended site for the Phase I Demonstration Plant is shown in Figure $3-2$. This location has sufficient size for two demonstration plants, one of which is planned to include HLW immobilization. The recommended site is near the AP Tank Farm and has room for all the interim storage options evaluated in this report.

The site previously proposed for the TWRS waste disposal production facilities is Area 4 of Figure $3-1$. This site has sufficient room for the HLW and LLW vitrification facilities, bulk raw material storage, and vitrified waste storage. This area was recommended for the TWRS production facilities but was not submitted for approval to the Site Selection Committee or the U.S. Department of Energy, Richland Operations Office because of the Privatization Initiative. 
WHC-SD-WM-ES-374

Revision 0

This page intentionally left blank. 


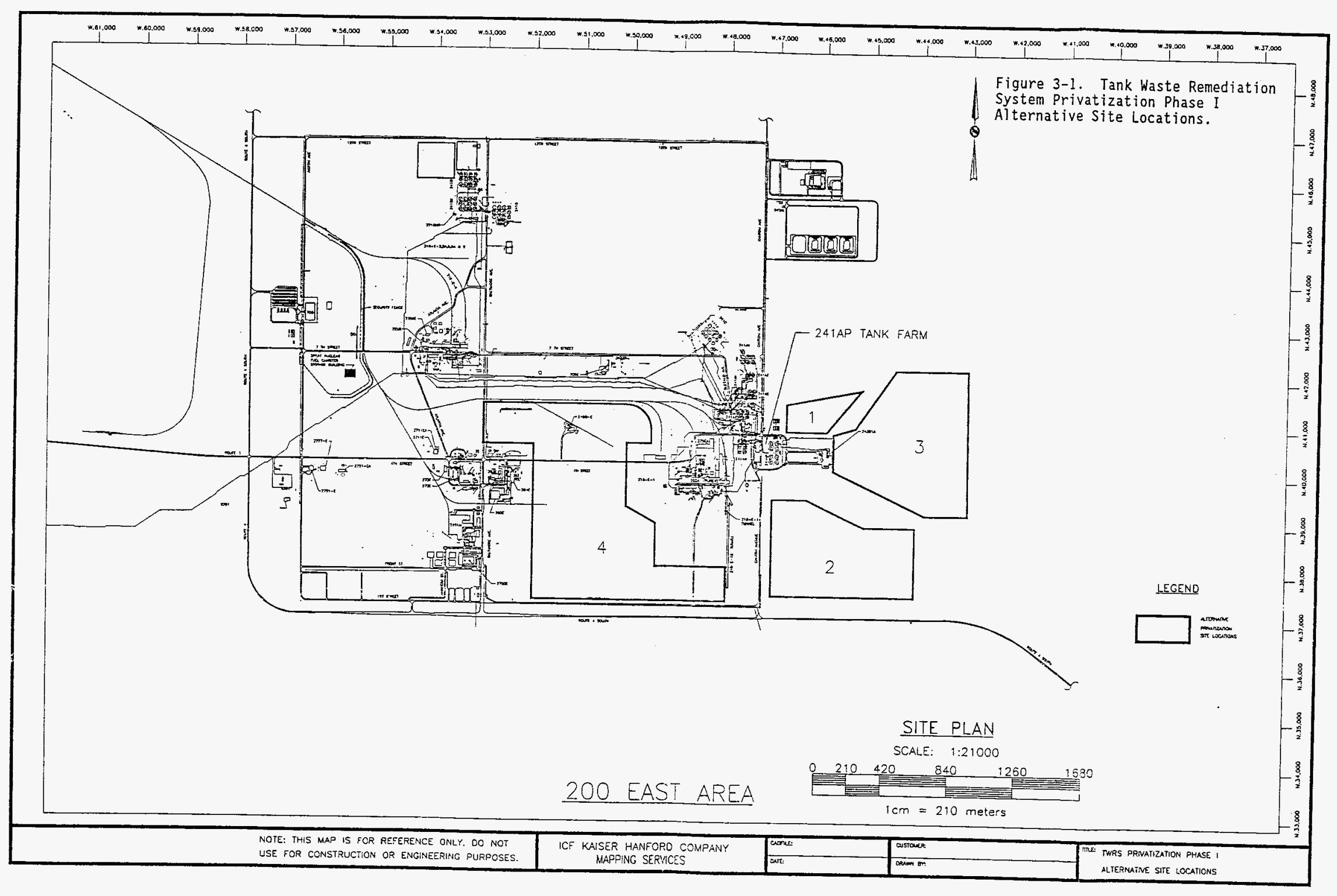




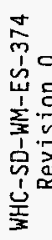

WHC-SD-WM-ES-374

Revision 0

\subsection{CRITERIA}

Criteria for evaluating Phase I and Phase II HLW interim storage options were established using design criteria for the canister storage facility discussed in WHC-SD-HWV-FDC-001, Hanford Waste Vitrification Plant Functional Design Criteria (Kalia 1992); The Future of Hanford: Uses and Cleanup--The Fina7 Report of the Future Site Uses Working Group (Drummond 1992); and the TWRS Privatization Request for Proposals (RL 1996). The criteria for Phase I and Phase II are as follows.

PHASE I

1. The storage facility will be required to meet Safety Class 2 criteria. This implies that the facility will meet the following requirements.

- The building structure must meet the seismic qualification criteria for Safety Class 2, nuclear, non-reactor facilities.

- The heating, ventilating, and air-conditioning (HVAC) system and the electrical, instrumentation, and control systems, which support the HVAC system, must meet Safety Class 2 criteria.

2. The facility will meet current DOE, federal, and Washington State Department of Ecology criteria for nuclear waste storage facilities.

3. The facility will have the capabilities to remotely handle, place, and retrieve individual canisters.

4. The facility will be capable of maintaining canister cooling air temperature and monitoring for potential contamination of the cooling air.

5. The facility will be capable of inspecting canisters during receipt, storage, and shipping.

6. The facility will be capable of remotely detecting a failed canister.

7. The facility will be capable of retrieving a failed canister and placing it into an overpack.

8. The facility will have the capacity to hold, as a maximum, 1,140 standard canisters of HLW. The physical properties of the standard canisters are as follows:

- Dimensions: $0.61 \mathrm{~m}$ diameter by $3.0 \mathrm{~m}$ long

- Nominal heat generation: $1 \mathrm{~kW}$ per canister.

The facility should be adaptable to accept Phase II canisters, which are the following size.

- Dimensions: $0.61 \mathrm{~m}$ diameter by $4.57 \mathrm{~m}$ Tong. 
9. To support the storage of secondary HLW and cesium, the Phase I interim storage facility should be capable of storing an additional 100 canisters of cesium and 53 standard canisters of secondary HLW. The cesium canisters have the following physical properties:

- Dimensions: $0.33 \mathrm{~m}$ diameter by $1.37 \mathrm{~m}$ long

- Heat generation: maximum of $1.5 \mathrm{~kW}$ per canister.

10. The interim storage facility should be located as close as possible to the Phase I Demonstration Plant. In accordance with the recommendation contained in The Future of Hanford: Uses and Cleanup--The Final Report of the Future Site Uses Working Group (Drummond 1992), the facility shall be within the 200 East and 200 West Areas.

11. The cost to modify a facility should be minimized.

PHASE II

1. The facility will have a capacity of 6,000 to 20,000 Phase II canisters, based on the estimate from the RFP. Given the range of capacity, requirements for storing the estimated 53 canisters of secondary $H L W$ were not considered separately. The Phase II canisters have the following physical properties:

- Dimensions: $0.61 \mathrm{~m}$ diameter by $4.57 \mathrm{~m}$ long

- Nominal heat generation: $1 \mathrm{~kW}$ per canister.

2. The Phase II storage facility should be located as close as possible to the Phase II waste treatment facility. 
WHC-SD-WM-ES-374

Revision 0

\subsection{ANALYSIS}

Previous reports were reviewed to determine if the facilities chosen met the established criteria. The facilities evaluated included the Hanford Site canyon buildings ( $B$ Plant, T Plant, $U$ Plant, and Plutonium-Uranium Extraction [PUREX]), Fuels and Materials Examination Facility (FMEF), Washington Nuclear Plant (WNP) Spray Ponds, CSB as designed, CSB with additional vaults, a new facility, and an offsite location.

\subsection{CANYON BUILDINGS}

The canyon buildings considered were B Plant (221-B), T Plant (221-T), $U$ Plant $(221-U)$, and PUREX (202-A). These facilities are all essentially the same in design and age except for PUREX, which was built 10 years later than the other three plants. Given the commonality of the facilities, the evaluation of them is combined. The following subsections provide a brief description of each plant.

\subsubsection{B Plant}

The B Plant, located in the 200 East Area, was constructed between August 1943 and February 1945 as a chemical separations plant for recovering nuclear materials using a bismuth phosphate process. The canyon building is $247 \mathrm{~m}$ long, $20 \mathrm{~m}$ wide, and $21 \mathrm{~m} \mathrm{tall}$. The facility became operational in April 1945 and operated until 1952. The B Plant was refurbished from 1961 to 1967, and restarted in 1968 for its second mission, to operate as a "waste fractionization plant" to remove cerium and promethium (1964 to 1968) and cesium and strontium from tank farm liquid waste. This mission was completed in 1985. The B Plant is currently undergoing deactivation activities.

\subsubsection{T Plant}

Construction of the T Plant began in the 200 West Area in June 1943 and was completed in October 1944. This was the first of the separations plants at the Hanford Site. The first batch of irradiated fuel rods from the B Reactor was processed from December 26-27, 1944. Fuei reprocessing activities were terminated in 1956. In 1957, T Plant resumed service as a decontamination and repair facility.

\subsubsection{U Plant}

The U Plant, located in the 200 west Area, was constructed as a chemical separations plant to recover nuclear materials using a bismuth phosphate process. Bechtel Hanford, Inc. maintains and operates the U Plant, which is undergoing decontamination and decommissioning. 
WHC-SD-WM-ES-374

Revision 0

\subsubsection{PUREX}

The PUREX Plant in the 200 East Area was constructed in 1953 with initial operation beginning in 1955. The building is $37 \mathrm{~m}$ wide by $329 \mathrm{~m}$ long. The PUREX solvent extraction (tributyl phosphate) system was used to separate and decontaminate uranium, plutonium, and neptunium produced by Hanford Site reactors. The PUREX Plant was operated from January 1955 until the end of September 1972. Operation resumed in November 1983 to process irradiated $\mathrm{N}$ Reactor fuels. The PUREX Plant closed in 1990 and deactivation activities are in progress.

Kaiser Engineers Hanford evaluated the 221-U Building and PUREX (Kaiser 1990) to determine their potential to store the $N$ Reactor fuel and Hanford Waste Vitrification Plant (HWVP) glass canisters. This review assumes that because the 221-B and 221-T Buildings were built at the same time and used the same design as the 221-U Building, the conclusions arrived at in the 1990 report also apply to the 221-B and 221-T Buildings.

\section{Evaluation}

1. Seismic

The B Plant structure was seismically evaluated (Murkowski 1989) and determined to meet Safety Class 2 criteria for nuclear, non-reactor facilities. The T Plant and U Plant are assumed to meet the same criteria. The PUREX Plant was assessed and determined to meet Safety Class 2 criteria (Appendix A).

2. State, Federal, and DOE Criteria for Waste Storage Facility

The facilities meet all applicable regulations, or could be modified to meet all applicable regulations (Kaiser 1990).

3. Remote Handling

In 1990, Kaiser determined that the existing canyon crane could be renovated to handle the canisters. The cranes in the $B, T$, and $U$ Plants have a 7.3-m lift from the crane hook to the canyon deck. The PUREX Plant 1 ift is approximately $12 \mathrm{~m}$. A closed-circuit television (CCTV) could be mounted on the cranes to provide inspection and viewing for remote operation.

4. Air Temperature and Contamination Monitoring

The current HVAC systems in B Plant cannot maintain the canister temperature (Kaiser 1990). The existing ventilation systems were not designed to remove the canister-generated heat load from the canyon areas. A completely new HVAC system meeting Safety Class 2 requirements would have to be installed. This system would consist of air supply equipment, an air distribution system, an electrical instrumentation and control system, and an electrical supply with redundant capabilities (such as a diesel engine ac power generator). In addition, an air exhaust system with high-efficiency particulate air (HEPA) filtration 
would have to be constructed in an adjacent building. The HEPA exhaust system is required as the secondary confinement barrier because the canisters would be stacked in a rack on the canyon floor and not placed inside a second sealed container.

Monitoring for radiation would be located at the HVAC system exhaust ports. Ventilation air exhaust would pass through HEPA filters, which would provide containment of possible airborne contamination from a failed canister. The temperature would be monitored by installing temperature measuring devices at various positions in the cooling air stream.

5. Canister Inspection Capabilities

In situ canister inspection could be accomplished using a CCTV camera mounted on the crane.

6. Failed Canister Detection and Recovery Capabilities

Retrieval will be accomplished by reversing the steps taken to store the canisters. Failed canister detection could be by CCTV or air monitoring equipment.

7. Facility Storage Capacity for Phase I

The canisters would be stored in the canyon area of the facility in steel storage racks (Kaiser 1990). Each storage rack would be $2.5 \mathrm{~m}^{2}$ and hold nine canisters (Figure 5-1).

The B, T, U, and PUREX canyons each contain approximately $2,700 \mathrm{~m}^{2}$ of usable floor space. It is estimated that each of these canyons can hold approximately 266 storage racks, each capable of holding nine canisters (Figure 5-2). This gives a total storage capacity of 2,400 canisters for each facility. Therefore, each of the canyon facilities could hold all the Phase I glass canisters.

8. Facility Storage Capacity for Secondary HLW and Cesium

The projected number of canisters for secondary HLW and cesium is 53 and 100 , respectively. The cesium canisters are significantly smaller than the vitrified HLW canisters. Based on the number of canisters, each facility will have storage space to accommodate the secondary $H L W$ and cesium canisters with the Phase I immobilized HLW.

\section{Facility Storage Capacity for Phase II}

Each canyon facility has a storage capacity of 2,400 canisters. A single canyon would not provide enough storage for the minimum number of canisters estimated for Phase II. The combined capacity of all the canyons, 9,600 canisters, satisfies the lower end estimate of the canisters from Phase II. 


$$
\begin{aligned}
& \text { WHC-SD-WM-ES-374 } \\
& \text { Revision } 0
\end{aligned}
$$

Figure 5-1. Multicanister Storage Rack.

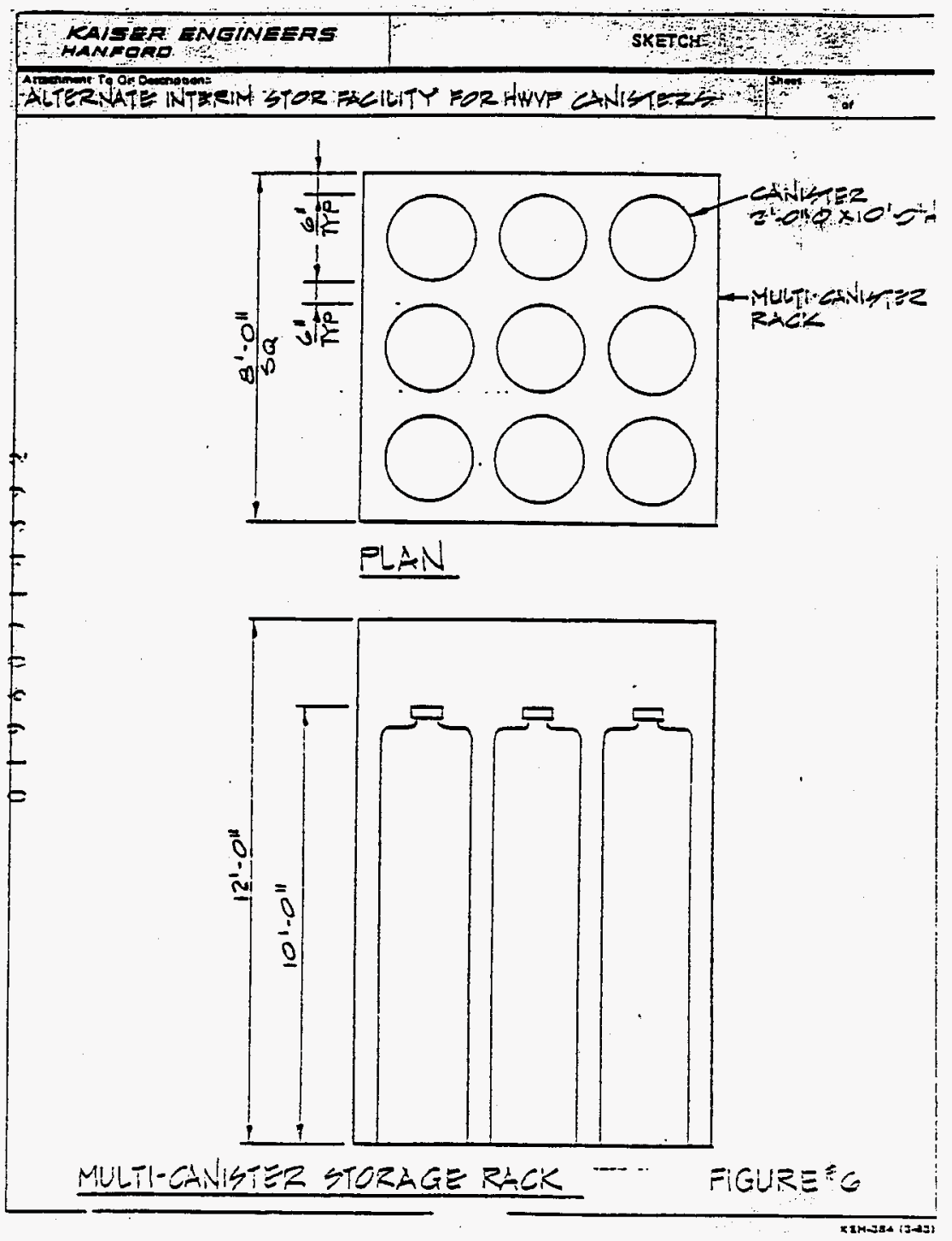

5-4 


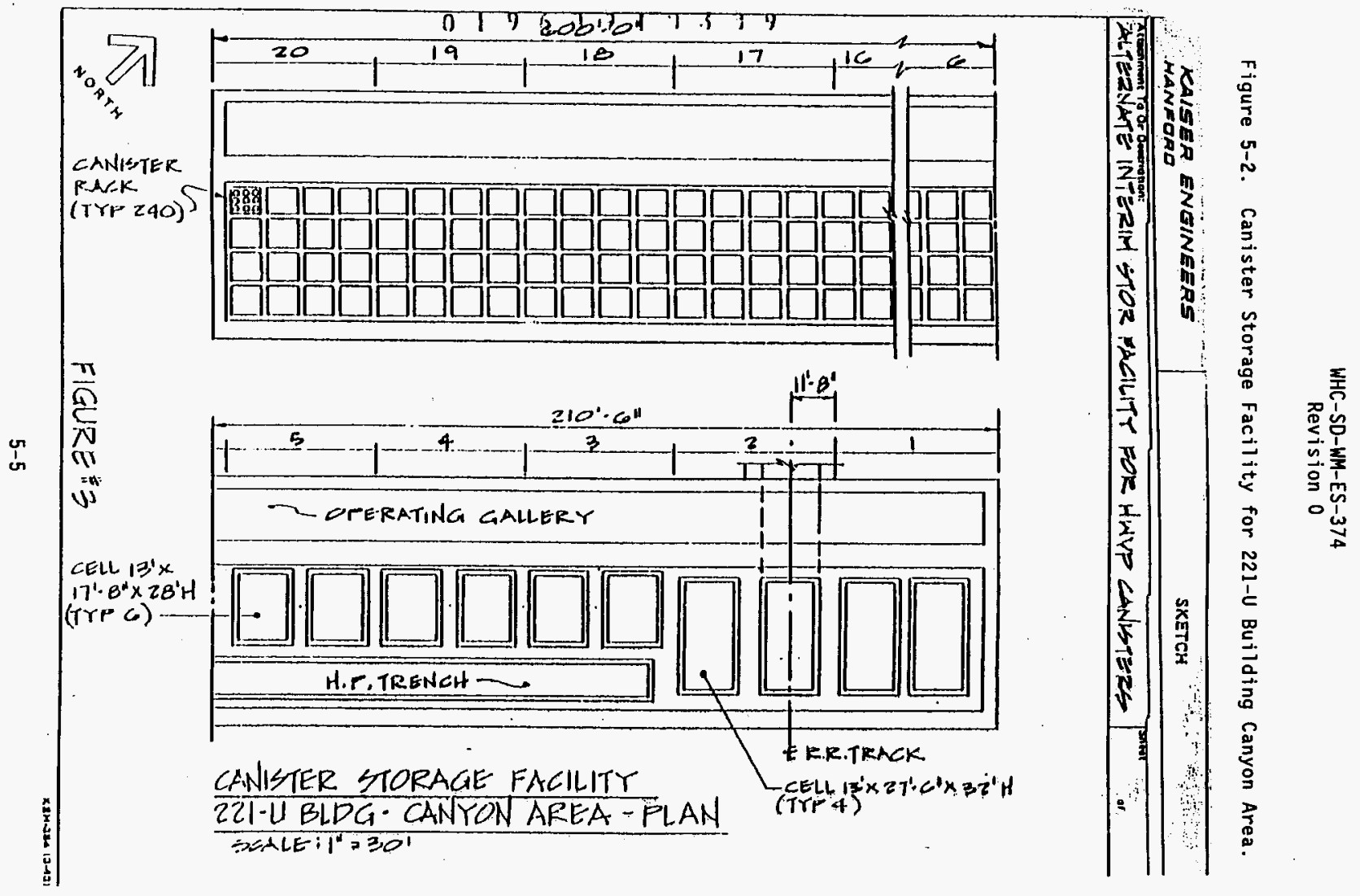


WHC-SD-WM-ES-374

Revision 0

\section{Facility Location}

The B Plant is located in the 200 East Area and is approximately $4 \mathrm{~km}$ from the Phase I plant. The T Plant is located in the 200 West Area and is approximately $10 \mathrm{~km}$ from the Phase I plant. The U Plant is located in the 200 West Area, and is approximately $11 \mathrm{~km}$ from the Phase I plant.

The PUREX Plant is located in the 200 East Area and is the closest of the canyon facilities to the Phase I plant. It is approximately $1.6 \mathrm{~km}$ from the Phase I plant to the PUREX Plant.

\section{Estimated Cost of Upgrade}

The estimated cost of upgrading the 221-U Building is \$28 million with $35 \%$ contingency (Kaiser 1990). The cost of upgrading the 221-B and 221-T Buildings is assumed to be similar. The cost in 1996 dollars is $\$ 32.7$ million. This cost does not include decontamination of the facility.

The estimated cost of upgrading PUREX is $\$ 24.8$ million (Kaiser 1990). The cost in 1996 dollars is $\$ 29$ million. This cost does not include decontamination of the facility.

\section{Additional Considerations}

The canyon facilities were used to process nuclear fuel into plutonium and waste reprocessing; as a result, they are highly contaminated. To accommodate the construction of the modifications required to store the Phase I product, the canyons would have to be decontaminated. This would be costly due to the level of contamination and the unknown situations that are associated with this type of work. Because decontamination methods only remove material from surfaces, there would still be contamination-related problems when modifications were made to the facility. In addition, there could be problems related to lead paint and asbestos removal if these materials were encountered during construction.

Extensive renovations would need to be made to the canyon to accommodate the storage of the HLW canisters (Kaiser 1990). This study of existing facilities for interim storage of HWVP canisters recommended that a new $30-\mathrm{cm}$ thick concrete slab be poured over the entire floor (cel1 cover blocks) of the canyon. The new concrete slab would support a raised steel floor which would hold the canister storage racks (Figure 5-3). These changes could potentially affect the safety class of the structure. For example, if a concrete wall were being core drilled during installation and some rebar was cut, the entire wall would have to be reanalyzed to determine whether these activities compromised the safety class of the wall. This is just one of many unknown situations that could potentially cause modification costs to exceed estimates.

The canyon alternative offers no segregation of the canisters. If a rupture or leakage of a canister occurs during storage, there is nothing to prevent the surrounding canisters from becoming contaminated. 
WHC-SD-WM-ES-374

Revision 0

Figure 5-3. Canister Storage Facility for 202-A Building (Plutonium-Uranium Extraction) Canyon Area Section.

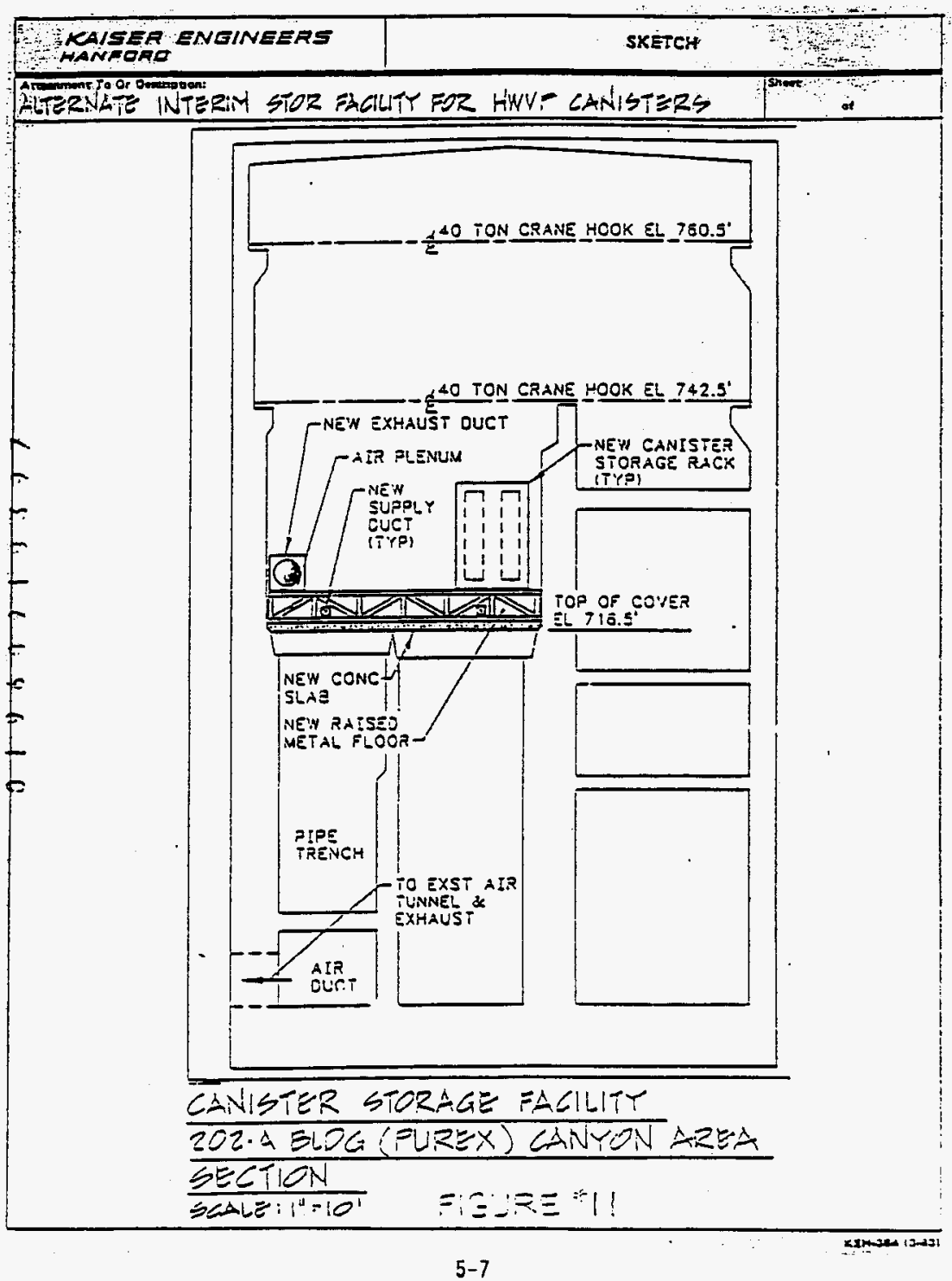


WHC-SD-WM-ES-374

Revision 0

Operating costs for this option would be high due to the large MEPA filtration systems.

\section{Recommendation}

Each canyon facility has the space to store the Phase I immobilized HLW, secondary HLW, and the cesium. The canyons are on the 200 Area Plateau and are located relatively close to the proposed Phase I plant site. However, the canyons are not recommended as a location for the interim storage of the Phase I HLW canisters because of the lack of existing design information, the decontamination and cleaning costs, and the amount of facility upgrades required.

The canyons also are not recommended for Phase II storage for the same reasons listed above.

\subsection{FMEF}

The FMEF was constructed in the 400 Area in 1979, and is a Safety Class 1 nuclear facility. The FMEF was built to examine and analyze the irradiated test assemblies from the Fast Flux Test Facility. The FMEF was never used for its initial purpose and has never been exposed to irradiated nuclear material. The FMEF was used to fabricate and assemble nuclear heat sources for space applications, but currently has no mission.

The FMEF contains two cells which have sufficient shielding to serve as storage areas for HLW canisters. The canisters would be transported to the FMEF via truck or rail. The canisters would be unloaded in the 300 Bay and placed in the upper nondestructive examination (NDE) cell and the unit process cell.

\section{Evaluation}

1. Seismic

The FMEF meets the seismic requirements.

2. State, Federal, and DOE Criteria for Waste Storage Facility

The facility meets all applicable regulations, or could be modified to meet all applicable regulations.

3. Remote Handling

Additional cranes would be required in the 300 Bay to unload the canisters and in each of the storage cells to remotely handle the canisters.

4. Air Temperature and Contamination Monitoring

Monitoring for radiation would be located at the HVAC system exhaust ports. Cooling air exhaust would be through HEPA filters which would 
WHC-SD-WM-ES-374

Revision 0

provide containment of possible airborne contamination from a failed canister. The temperature would be monitored by installing temperature measuring devices at various positions in the cooling air stream.

5. Canister Inspection Capabilities

In situ canister inspection could be accomplished using a CCTV camera mounted on the crane.

6. Failed Canister Detection and Recovery Capabilities

Retrieval would be accomplished by reversing the steps taken to store the canisters. Failed canister detection could be by CCTV or the air monitoring equipment.

7. Facility Storage Capacity

Allowing $0.5 \mathrm{~m}^{2}$ for each canister, the required area for Phase 1 canisters is approximately $700 \mathrm{~m}^{2}\left(1,350 \times 0.5 \mathrm{~m}^{2}\right)$. The available storage space in the FMEF is $530 \mathrm{~m}^{2}$ (WHC 1993). Canisters in the upper NDE cell could be stacked two high to provide more capacity. Stacking, canisters two high in the upper NDE cell would add approximately $300 \mathrm{~m}^{2}$ of storage space for a total storage capacity of $830 \mathrm{~m}^{2}$. However, this would make inspection and retrieval of any canister on the lower level very difficult. It also would increase the potential of contaminating other canisters if a canister leaks.

8. Facility Storage Capacity for Secondary HLW and Cesium Canisters

If canisters were stacked two high in the upper NDE cell, the FMEF would have the capacity to store the secondary HLW.

The Fuel Assembly Area (FAA) in the FMEF could be used to store the cesium canisters. The FAA has a storage rack that was designed to hold fuel assemblies before they were placed into the Fast Flux Test Facility. The racks are mechanically ventilated. The opening size of the fuel racks would have to be reviewed to determine whether the cesium canisters would fit.

9. Facility Location

The FMEF is located outside the 200 Area Plateau approximately $16 \mathrm{~km}$ from the proposed site of the Phase I plant, therefore making it an unattractive location. The 200 Area has been targeted as the preferred waste storage site.

10. Cost

The cost of upgrades to the FMEF is unknown. In several of the references cited, cost estimates were made to modify the FMEF to store different types of fuel or wastes. None of the material forms are close enough to the glass canisters to make the cost estimates usable. 
WHC-SD-WM-ES-374

Revision 0

\section{Additional Considerations}

The FMEF would meet the storage capacity for 1,350 canisters if canisters can be stacked two high in the upper NDE cell. This would require further investigation of floor loading, clearance height, etc., to verify if this is possible.

The heat generated by the canisters may be greater than the existing HVAC system can remove without exceeding the canister temperature limit and/or the facility concrete temperature limit. This must be investigated.

The height of the unit process cell may not allow the canisters to be placed in a rack system by an overhead crane. An alternative system may have to be designed to hold the canisters in place.

\section{Recommendation}

The FMEF is a Safety Class 1 facility, it is not contaminated, and it has no current mission. It is possible to store the Phase I canisters in the FMEF if they can be stacked two high in the upper NDE cell. The FMEF is not located on the 200 Area Plateau and would require significant modifications to store the HLW canisters. It is recommended that a further study of the FMEF be done to determine the cost and technical viability of using the FMEF for interim storage if a more suitable option is not found.

\subsection{WNP-1 AND WNP-4 SPRAY PONDS}

The WNP-1 and WNP-4 Spray Ponds were designed as a safety-related structure for holding a 30-day water supply for use by their reactors following a reactor coolant loss. The Spray Ponds are identical in design. The Spray Pond concrete structures were essentially complete when the reactors were terminated. Mechanical and electrical equipment have not been installed in the WNP-4 Spray Pond; water spray piping has been installed in the WNP-1 Spray Pond. Both facilities have been maintained in good condition and meet U.S. Nuclear Regulatory Commission requirements for a nuclear reactor facility.

The Spray Ponds would require extensive modification to store the HLW canisters. To stack the canisters two high, the walls of the ponds would be raised $1.5 \mathrm{~m}$. A rack system and operating deck would be installed in the basin to hold the canisters, and a crane system to move the canisters would have to be designed and installed. In addition, a structure covering the entire pond would have to be built, and an HVAC system to ventilate the structure would be required (Figures 5-4 through 5-7).

The WNP-1 Spray Pond was evaluated to determine whether it could be used to store the entire inventory of vitrified HLW canisters (Carlson 1995). The following information was obtained from this study. 







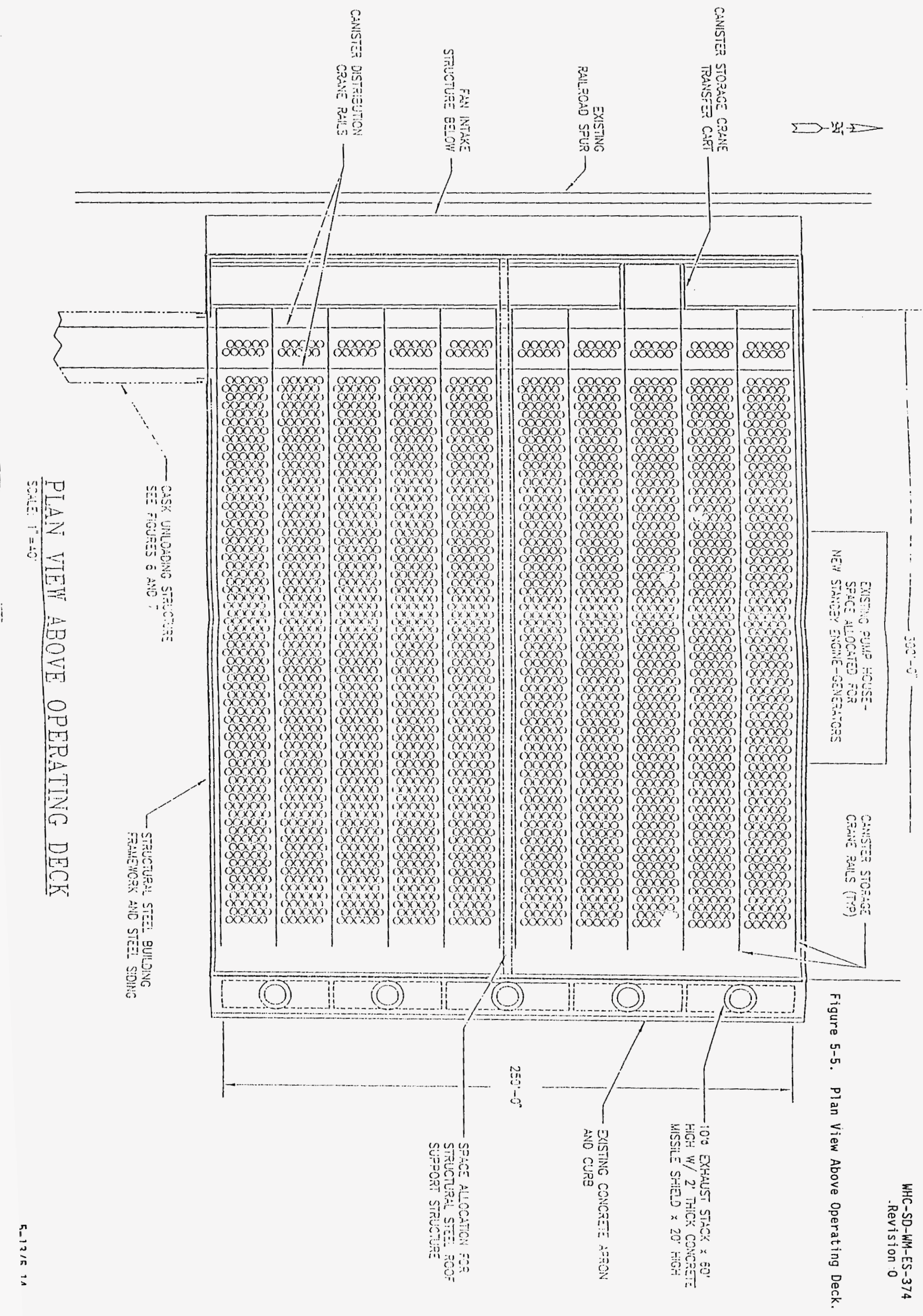



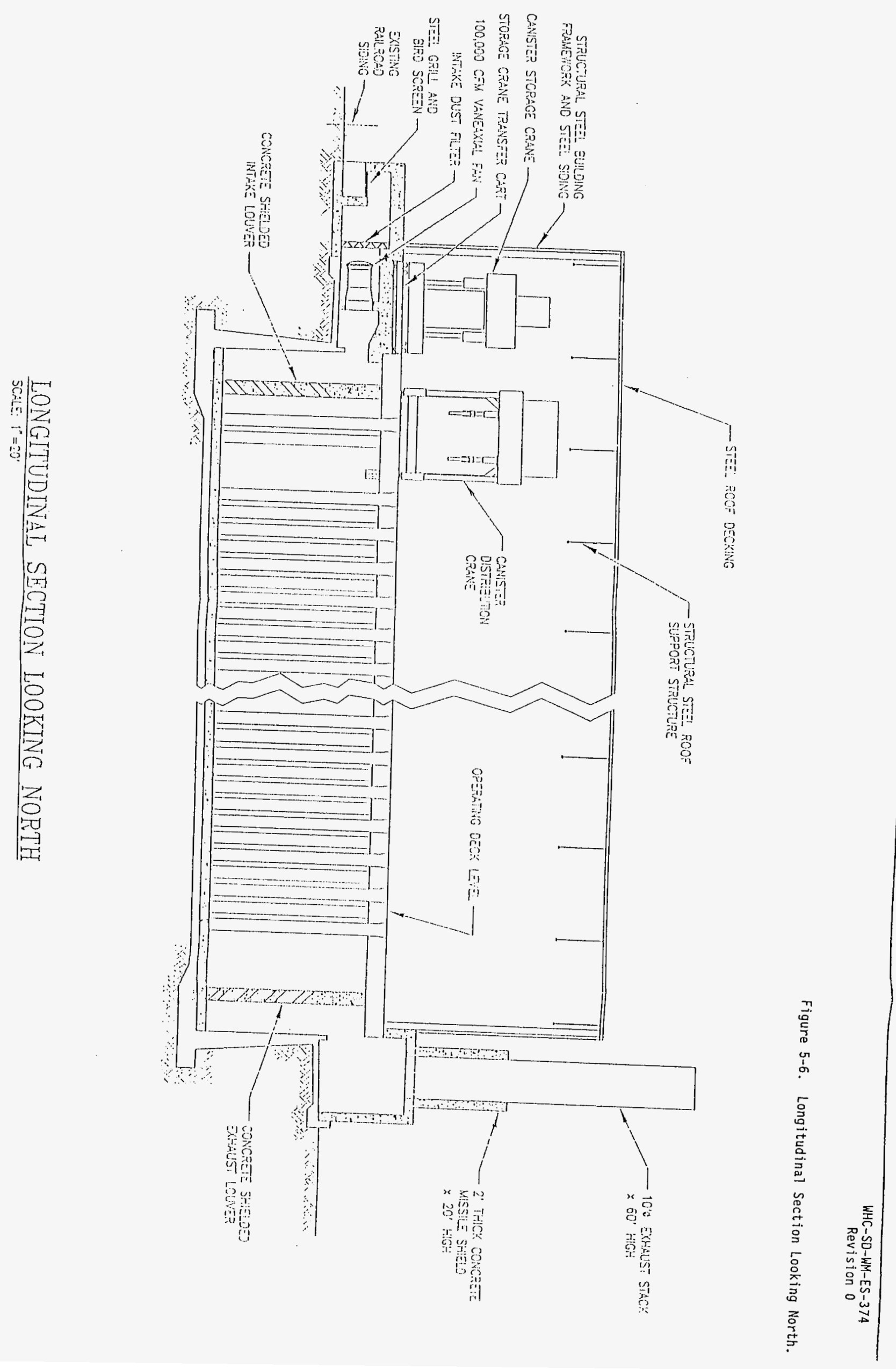


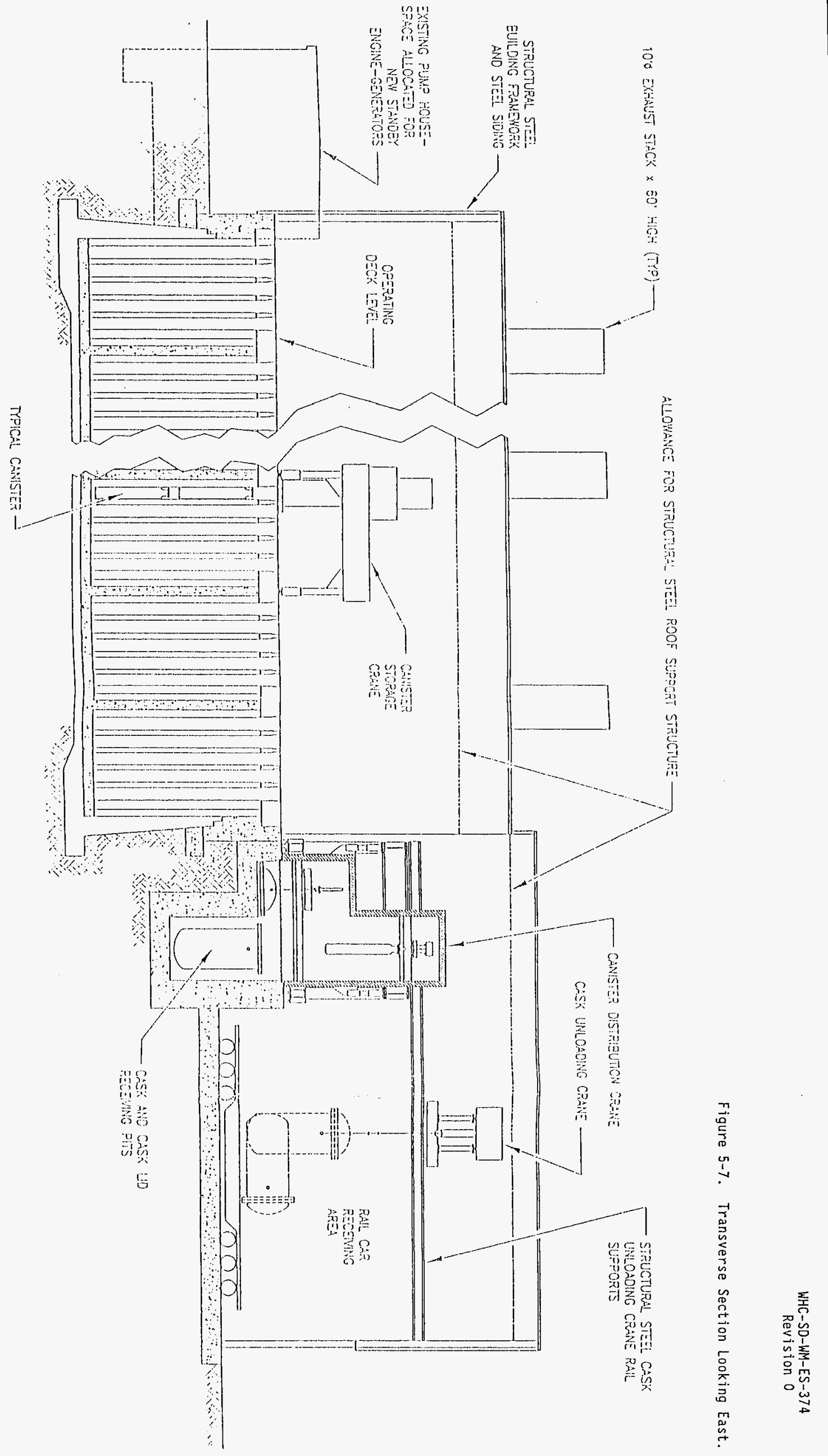




\section{Evaluation}

1. Seismic

The existing structures are Safety Class 1 and designed to withstand a design basis earthquake.

2. State, Federal, and DOE Criteria for Waste Storage Facility

The facilities meet all applicable regulations, or could be modified to meet all applicable regulations.

3. Remote Handling

Remote handling cranes would need to be installed. Each facility would require three rail-mounted cranes.

4. Air Temperature and Contamination Monitoring

Monitoring for radiation would be located at the HVAC system exhaust ports. Because the multicanister overpacks (MCO) would be stored in open racks inside the Spray Pond, the HVAC system would provide secondary confinement of the HLW. Cooling air would be exhausted through HEPA filters. The temperature would be monitored by installing temperature measuring devices at various positions in the cooling air stream.

\section{Canister Inspection Capabilities}

In situ canister inspection could be accomplished using a CCTV camera that is mounted on the crane.

6. Failed Canister Detection and Recovery Capabilities

Retrieval would be accomplished by reversing the steps taken to store the canisters. Failed canister detection could be by CCTV or air monitoring equipment.

7. Facility Storage Capacity for Phase I

Each facility is nearly square in plan with approximately 6,972 $\mathrm{m}^{2}$ of floor space. Each facility has the capability of storing all the vitrified HLW canisters from Phase I.

8. Facility Storage Capacity for Secondary HLW and Cesium canisters

Each facility has the capacity to store the secondary HLW and the cesium canisters.

9. Facility Storage Capacity for Phase II

Each facility is nearly square in $\mathrm{plan}$ with approximately $6,972 \mathrm{~m}^{2}$ of floor space. Allowing $0.5 \mathrm{~m}^{2}$ for each canister, a total of $10,000 \mathrm{~m}^{2}$ 
would be required to store all the estimated 20,000 canisters from Phase II. Both Spray Ponds would be needed to provide sufficient storage space for Phase. II.

10. Facility Location

The WNP Spray Ponds are approximately $16 \mathrm{~km}$ from the proposed site of the Phase I plant. The Spray Ponds are not located on the 200 Area Plateau, therefore making this a comparatively unattractive location.

11. Estimated Cost

The cost of upgrading the WNP-1 Spray Pond is $\$ 271.3 \mathrm{million}$ (Carlson 1995, Table 6.7-17). This cost is for construction/modification escalated with contingency. The cost for modifying WNP-4 is assumed to be the same.

The cost to upgrade the Spray Ponds includes construction of a new unloading facility next to the pond, a railroad spur, a receiving pit, an unloading crane, a distribution crane, addition of a canister handing system, enclosure of the Spray Pond, cask unloading facilities, and a Safety Class 2 HVAC system.

\section{Additional Considerations}

The WNP Spray Ponds currently belong to the Washington Public Power Supply System. Ownership of the Spray Ponds would have to be transferred to the DOE.

\section{Recommendation}

The Spray Ponds are not recommended for storage of the Phase I HLW canisters because of the high cost to modify the ponds. However, the Spray Ponds are a viable alternative for storage of the Phase II canisters. The total cost to retrofit both ponds is estimated at approximately $\$ 550$ million. This is the lowest cost alternative of all the storage options for storing the high-end estimate of Phase II canisters.

\subsection{CSB FOR PHASE I AND PHASE II HLW}

The CSB was originally designed to store canisters of vitrified HLW in three underground vaults. Work on the CSB was terminated when that project was canceled in 1993. The CSB was turned over to the SNF Project in 1995 to store canisters of fue] from the $K$ Basins. As a result of the new mission, the CSB has undergone some redesign to accommodate the SNF canisters. Fluor Daniel, Inc. has studied the technical feasibility of storing the Phase I canisters in the CSB. 
WHC-SD-WM-ES-374

Revision 0

Evaluation

1. Seismic

The CSB vault is a Safety Class 1 structure. The facility will have safety class electrical, instrument, and control systems.

2. State, Federal, and DOE Criteria for Waste Storage Facility

The CSB is designed to meet all the current requirements for nuclear waste storage facilities.

3. Remote Handling

The CSB will have the capability to remotely handle the canisters using the MCO handling machine.

4. Air Temperature and Contamination Monitoring

The CSB storage vaults are designed for natural convection cooling.

Outside air enters one side of a vault and exits through a stack on the other side. This design eliminates the need for a forced-air cooling system. The exhaust stack for each vault will be monitored for contamination in the exhaust air.

5. Canister Inspection Capabilities

The CSB will have an MCO inspection station for venting and inspecting the MCO when it arrives from the K Basins. This station could be used to inspect HLW canisters.

6. Failed Canister Detection and Recovery Capabilities

The CSB will be capable of identifying failed canisters in a storage tube by sampling the atmosphere inside the tube. Retrieval of a failed canister would be the reverse of placing a canister into a storage tube.

7. Phase I Storage Capacity

The CSB contains three storage vaults. Each CSB vault will contain 220 storage tubes capable of holding three standard canisters for a total of 660 canisters per vault. The SNF Project will be using only one of the three vaults in the CSB. The other two vaults will be available to store the HLW canisters. One complete vault and most of the second vault would be needed to store the Phase I HLW canisters.

8. Facility Storage Capacity for Secondary HLW and Cesium canisters

The secondary HLW canisters could be stored in the unused portion of the second vault. The cesium canisters could also fit into the CSB if three canisters could be put into each storage tube. This is technically feasible because the cesium canisters are smaller than the standard canisters. 
WHC-SD-WM-ES-374

Revision 0

9. Phase II Storage Capacity

The CSB could be expanded to add three vaults to the south end of the building. Further expansion to the south is limited by a concrete ditch that surrounds the old HWVP site. The operations and support areas for the CSB are located on the north end of the CSB preventing expansion in that direction.

Adding three vaults would provide room for approximately 2,000 standard canisters. This does not meet the minimum storage criteria of 6,000 canisters for Phase II.

10. Facility Location

The CSB is located on the 200 Area Plateau approximately $5 \mathrm{~km}$ from the proposed Phase I site. This meets the criterion that the waste remain on the 200 Area Plateau.

\section{Estimated cost}

The Fluor Daniel, Inc. estimate to modify two vaults is $\$ 32$ million (Fluor 1996). Additional vaults could be added at a cost of $\$ 28$ million per vault.

\section{Recommendation}

The CSB is the recommended option to store the Phase I HLW canisters, secondary HLW, and cesium canisters. The CSB was originally designed to store canisters of vitrified HLW glass from the HWVP and would be easily modified to store the current HLW canisters. With the addition of a fourth vault, the CSB would have storage space for all the expected canisters from Phase I at the lowest cost.

The CSB is not recommended for storing the Phase II canisters because it cannot be expanded enough to provide storage for the HLW canisters.

\subsection{NEW FACILITY FOR PHASE I STORAGE}

Three dry storage systems are available that would satisfy the requirements for Phase I interim storage: standalone casks, housing arrays, and vault storage. All three systems would be designed and built to meet the requirements identified in section 4.0 of this report. These three systems are described in WHC-SD-CP-ES-155, Commercially Available Dry Storage Systems for Storage of Irradiated Fuel on the Hanford Site (Monthey 1994).

\subsubsection{Standalone Casks}

Several standalone cask systems have been designed to hold commercial fuel, and they take into account shielding thickness, heat removal, and criticality spacing requirements. In general, these cask systems consist of an inner container or basket, a transfer system, and a storage cask. 
Irradiated fuel assemblies are put in the basket, which is then placed into the cavity of a transport or storage cask. The cask is then transported to, and unloaded at, a storage facility.

The majority of the standalone casks have been designed only for onsite transfers and will require an onsite safety analys is report for packaging (SARP). Some of the casks have been licensed for offsite transfer, which may be a benefit when a decision is made regarding final disposition of the canisters. In addition to the SARP, the Phase I storage location also will require a final safety analysis report.

The inner fuel containers incorporate criticality spacing and/or neutron poisoning schemes that are specific to the containers' preapproved, commercial cask storage system. These existing inner containers may prove to be unnecessary for storage of the Phase I vitrified HLW canisters and the cesium and technetium canisters. Although the inner container design for the Phase I canisters can be expected to be considerably less complex than the design for irradiated fuel assemblies, the design will have to be evaluated. The required canister spacing inside the container will determine the number of casks required to store the Phase I glass. This will determine the economic viability for the various types of standalone cask systems.

A standalone cask system for the Phase I HLW involves the canisters being loaded into an inner container. The inner container is partitioned to hold as many canisters as the cavity of the cask allows and has a sealable lid that provides secondary containment. The container is then placed into a transport cask or the storage cask for transfer to the storage pad. The Demonstration Plant scope contains the requirement to place the canister into a transport cask. The standalone cask system requires the additional step of placing the canisters into a container and sealing the container. Depending on the cask system used, the seal is either a mechanical 0-ring seal or the container is welded closed. This requirement will have to be added to the scope of the Demonstration Plant or a facility will have to be built to transfer the canister from one transport cask to the inner container and then to a new transport cask.

At the storage pad, the inner container is removed from the transport cask and placed in the storage cask, or the storage cask is removed from the transport vehicle and placed on the pad. The transfer cask/storage cask used in these systems range in weight from approximately 91 to 172 MT. The manufacturers of these systems can provide specialized handling equipment to load, transport, and place the casks. The following descriptions of the standalone cask systems are taken directly from WHC-SD-CP-ES-155

(Monthey 1994).

\section{MC-10 Storage Cask}

This cask can be stored vertically or horizontally attached to a storage skid on an outdoor concrete pad. All required shielding is contained within the cask. The internal basket is made from stainless steel. The cask body is a thick-walled, forged, low-alloy steel cylinder with external longitudinal fins for heat dissipation. The annulus between the outer steel plates of the cask wall and the trough between the fins is 
filled with a neutron-absorbing resin. The cask is closed at the top end by installing three covers in sequence. Two covers are sealed with metallic 0-rings with the third cover welded over the other two. Two penetrations with dual spring-energized metallic 0-ring seals permit leak testing. The internal cavity length is $413 \mathrm{~cm}$ and the diameter is $173 \mathrm{~cm}$. Internal pressure of the cavity is limited to $2.2 \mathrm{~atm}$ and the loaded weight is approximately 103 MT.

2. NAC-S/T Storage Cask and the NAC-STC Dual-Purpose Cask

The cavity length of the NAC-S/T storage cask is $417 \mathrm{~cm}$ and the cavity diameter is $164 \mathrm{~cm}$. Fuel criticality is controlled by its placement in a basket assembly made from aluminum and borated aluminum. The cask wall is $19 \mathrm{~cm}$ thick with layers of stainless steel, lead, and more stainless steel. The outer walls are covered with $18 \mathrm{~cm}$ of solid neutron-absorbing material, with imbedded copper and stainless steel heat-dissipating fins. The top has a single lid made from $17 \mathrm{~cm}$ of stainless stee 1 and $5.1 \mathrm{~cm}$ of lead. The cask weighs approximately 91 MT when fully loaded and has lifting and rotation trunions.

The NAC-STC dual-purpose cask is similar to the NAC-S/T, but with an additional $1 \mathrm{id}$, impact 1 imiters, and some dimensional differences. The cask cavity is $419 \mathrm{~cm}$ in length and $180 \mathrm{~cm}$ in diameter. The wall thickness is reduced to $14 \mathrm{~cm}$, the bottom thickness increased to $14.5 \mathrm{~cm}$, and the stainless steel portion of the lid is increased to $18 \mathrm{~cm}$, with the $5.1 \mathrm{~cm}$ of lead replaced with BISCO. This cask has an additional 14-cm thick stainless steel lid, which is considered as containment for transportation only. The load handling weight is $113 \mathrm{MT}$ with the impact limiters.

3. Transnuclear TN-12Y

This was developed for use as a transportation cask. The inner cavity is $122 \mathrm{~cm}$ in diameter and $457 \mathrm{~cm}$ long. The wall thickness is approximately $30 \mathrm{~cm}$ and is made from a new ferritic steel material (ASME SA-350, Grade LF3). The cavity is closed with a $36-\mathrm{cm}$ thick lid, with two concentric Viton 0 -rings and 40 bolts facilitating 1 id closure. The lid has a vent and a water-flush opening, with a drain tube located at the bottom of the shell. The surfaces of the cask body are clad with a layer of stainless steel, which is covered with a $10.2-\mathrm{cm}$ thick layer of neutron-shielding resin material. The 288 longitudinal cooling fins are welded to the outside surface of the shell and extend through the resin layer. Three sets of trunions are welded to the cask body for handling, rotating, and tying down the cask. Impact limiters can be attached to either end of the cask during transport, where the usual mode is via a specially designed rail car. The loaded weight for transport is 97 MT.

\footnotetext{
"Viton is a trademark of E. I. du Pont de Nemours \& Company.
} 
4. Transnuclear TN-24

The inner cavity is $415 \mathrm{~cm}$ 1ong and $160 \mathrm{~cm}$ in diameter. The inner basket is made from copper-coated, borated stainless steel. The carbon steel cask body is $24 \mathrm{~cm}$ thick with an outer shell thickness of $1.9 \mathrm{~cm}$. It is welded to a bottom $p l a t e$ and attached to a top closure flange. The top is formed by a welded flange forging bolted to a flanged carbon steel top 1id $27 \mathrm{~cm}$ thick. The bottom thickness is also $27 \mathrm{~cm}$. There are two penetrations (vent and drain) in the lid. The lid closure has double metallic 0-ring seals and the cask is helium filled. A domed weather cover is provided above the lid. An array of resin-filled aluminum containers, aligned vertically around the cask and enclosed by an outer steel shell, provides neutron shielding and heat dissipation. The total weight is 97 MT.

5. Transnuctear TN-BRP and TN-REG

The TN-BRP and the TN-REG are almost identically made casks, using a new ferritic steel material (ASME SA-350, Grade LF3). The TN-BRP cavity is $434 \mathrm{~cm}$ long with a diameter of $163 \mathrm{~cm}$. The wall thickness is $24 \mathrm{~cm}$ and it weighs 98 MT. The TN-REG cavity is $415 \mathrm{~cm}$ long with a diameter of $182 \mathrm{~cm}$. The wall thickness is slightly thinner at $23.5 \mathrm{~cm}$ and weighs 102 MT. These casks have minimal neutron shielding, which may or may not be required for the Phase I HLW canisters. The casks are equipped with impact 1 imiters, and were designed to be transported by rail in a horizontal position, but may be stored vertically. Both casks have access and vent ports and two gas sampling ports for leak testing. For storage purposes, a secondary seal (1id) may be appropriate, which the current cask design does not include.

6. Whiteshell Nuclear Research Establishment (WNRE) Silo Storage Cask

In the WNRE silo storage cask, fuel is placed in unshielded storage baskets, transferred in a shielded cask, and placed in a concrete cask at the storage area. The cylindrical reinforced concrete storage cask is $6.7 \mathrm{~m} 25 \mathrm{~cm}$ high by $3 \mathrm{~m} 2.5 \mathrm{~cm}$ in diameter $(307 \mathrm{~cm})$ and rests on a reinforced concrete pad. An inner steel 1 iner surrounds the cavity, which is $75 \mathrm{~cm}$ in diameter and $300 \mathrm{~cm}$ long. The cavity depth may need to be slightly increased to accommodate a new inner container and the Phase I canisters, which are also $300 \mathrm{~cm}$ long. The concrete top plug is lined with lead and steel. Lifting lugs are embedded into the top of the concrete cask, which also has a top cover. The cask has two welded confinement systems, but no test port for measurements.

7. Castor $V / 21$

The Castor $V / 21$ has a one piece, cylindrical, ductile cast-iron/graphite cask body, which is stored upright on an outdoor pad. The cask cavity has a diameter of $153 \mathrm{~cm}$ and a length of $415 \mathrm{~cm}$. The sidewall thickness is $38 \mathrm{~cm}$, excluding the circumferential cooling fins. The loaded wight of the cask is 106 MT. Four trunions, two at the top and two at the bottom of the body, are bolted on. Two concentric rows of axial holes in the wall are filled with polyethylene rods for neutron shielding. The 
cask has primary and secondary lids made from stainless steel, a polyethylene slab insert, and seals to provide leak tightness. The primary 1 id is $29 \mathrm{~cm}$ thick and the secondary lid is $8.9 \mathrm{~cm}$ thick. There are two penetrations used for flushing, venting, and leak testing. An impact limiter is used on either end of the cask when it is transferred.

8. Ventilated Storage Cask (VSC) System

In the VSC system, irradiated fuel is contained in a multiassembly sealed basket (MSB) that is stored vertically in the central cavity of a ventilated concrete cask (VCC). For commercial nuclear fuel applications, the MSB is sealed by welding the shield and structural lids, vacuum drying, and refilling with helium before being placed in a separate shielded transfer cask. The MSB is transferred to the VCC in the transfer cask and inserted. The existing MSB, which fits inside the reinforced concrete cask, consists of a $157-\mathrm{cm}$ outside diameter steel shel1 (2.5 cm thick) and compartments for boiling water reactor (BWR) or pressurized water reactor (PWR) fuel. The MSB would be modified to accommodate Phase I canisters. The top of the MSB is covered with a shield lid and structural 1id. The lid combination provides a total of $25 \mathrm{~cm}$ of steel and $5.1 \mathrm{~cm}$ of neutron-absorbing concrete for shielding. The VCC has a $179-\mathrm{cm}$ inside diameter internal cavity formed by a $4.4-\mathrm{cm}$ thick steel cylinder and is $419 \mathrm{~cm}$ long. The concrete wall is $74 \mathrm{~cm}$ thick. Four steel-lined penetrations (air ducts) allow for heat removal by natural circulation. The top of the VCC is covered by a $1.9-\mathrm{cm}$ thick steel plate. Because of its size, a 136-MT crane will be required for handling a fully loaded VSC.

9. Interim Storage Cask (ISC) System

The ISC system is intended to provide interim aboveground storage for Fast Flux Test Facility irradiated fuel assemblies and fuel pin containers. The fuel is sealed in an unshielded container called the core component container (CCC) which is placed in the ISC, a shielded cask. Because the inside diameter of the cavity is only $56 \mathrm{~cm}$, the ISC design would have to be modified to accommodate the $61-\mathrm{cm}$ diameter Phase I HLW glass canisters. This system will not be considered for the Phase I storage facility.

\section{Babcock and Wilcox (B\&W) CONSTAR*}

The B\&W CONSTAR storage system consists of a sealable fuel basket, a shielded sleeve with a lifting device, and a concrete dry storage cask. The shielded sleeve provides sidewall shielding for the basket during fuel loading and may not be required for loading of Phase I glass

canisters. It is made from a $12.1-\mathrm{cm}$ thick shell of borated concrete and a $7.3-\mathrm{cm}$ thick lead shell which are sandwiched between outer and inner cylinders of $2.5-\mathrm{cm}$ thick carbon steel. The fuel basket would need to be redesigned to accommodate Phase I glass canisters and be attached to the thick composite concrete and steel bottom of the cask. The inside

\footnotetext{
"CONSTAR is a trademark of Babcock \& Wilcox.
} 
diameter of the cask cavity is $184 \mathrm{~cm}$ and it is $439 \mathrm{~cm}$ long. The reinforced concrete storage cask is $582 \mathrm{~cm}$ long with an outside diameter of $285 \mathrm{~cm}$, exclusive of its condensing fins. The inner 1iner is $2.54-\mathrm{cm}$ thick carbon steel. Leak testing ports are available to monitor primary and secondary containment welds. The total weight of the cask and its contents (e.g., BWR fuel) is 172 MT.

\section{Evaluation}

1. Seismic

The standalone cask systems that are commercially available have (onsitespecific) Certificates of Compliance (COC) issued by the U.S. Nuclear Regulatory Commission. A CoC indicates that the cask complies with the requirements of 10 CFR 72, "Licensing Requirements for the Independent Storage of Spent Nuclear Fuel and High-Level Radioactive Waste."

Included in the requirements of Part 72 are seismic evaluations to ensure the safe storage of the commercial fuel.

2. State, Federal, and DOE Criteria for Waste Storage Facility

The standalone casks and storage pad are designed to meet all state, federal, and DOE criteria for a waste storage facility.

\section{Remote Handling}

Because the cask provides shielding of the HLW glass canisters, remote handling equipment will not be required on the storage pad. The retrieval and recovery facility will require remote handling equipment.

4. Air Temperature and Contamination Monitoring

The casks are designed to transfer heat to the ambient air without any mechanical systems. Each cask does have a limit to its heat transfer capabilities and the system chosen will have to be evaluated for this criterion. Primary confinement is provided by the inner container which is seal welded before being put into the cask. The cask provides the secondary confinement. Leakage of the inner container is monitored by filling the annulus between the container and cask with a gas and then routinely checking the gas for radioactivity and pressure.

5. Canister Inspection Capabilities

Canister inspection will require the removal of the inner container from the cask and taking it to a facility where the container can be opened and inspected.

6. Failed Canister Detection and Recovery Capabilities

A failed canister cannot be detected unless the sealed container in which it is stored also fails. A standalone cask system will require a facility in which to inspect and recover failed containers and/or canisters. This facility could be designed as part of the Phase I 
WHC-SD-WM-ES-374

Revision 0

Demonstration Plant or as a separate facility. The inspection/recovery facility would have to remain operational for the lifetime of the storage facility.

\section{Facility Storage Capacity}

Criticality evaluation, radioactivity analysis, heat dissipation considerations, or limits on payload weight are factors that could influence the number of HLW canisters loaded into commercially available standalone cask systems. However, in determining the required capacity for the Phase I storage facility, only cask size limitations are considered. The parameters for each cask system for a storage facility with a capacity for 1,000 canisters are presented in Table 5-1. Depending on the type of system chosen, each cask can hold one to five glass canisters. Outside diameters of the standalone casks range from about $1.8 \mathrm{~m}$ (TN-12Y) to $2.9 \mathrm{~m}$ (B\&W CONSTAR). Based on the larger diameter, a storage area allowance of $37 \mathrm{~m}^{2}$ is made for each cask. For a cask system that holds one canister, Phase I storage for 1,000 canisters requires $400,000 \mathrm{ft}^{2}$ or about $3.6 \mathrm{ha}$. Using the same space allowance for casks holding five canisters, the required storage area is $80,000 \mathrm{ft}^{2}$ or about $0.8 \mathrm{ha}$.

8. Facility Storage Capacity for Secondary HLW and Cesium Canisters

Because of the relatively small volume, the secondary HLW and cesium canisters from Phase I could be included in these standalone cask systems with minimal impact to the overall size and cost of the storage facility. This is based on providing additional storage for 53 secondary HLW canisters and 158 cesium canisters. For example, using the smallest and least expensive cask (WNRE silo storage cask), 80 additional casks at a cost of $\$ 14.3$ millition would be needed for storage of secondary waste and cesium canisters. By comparison, the total number of casks needed to store the 1,137 Phase I canisters is $\$ 180$ million. For a larger cask system (e.g., TN-24), 22 additional casks would be required for storage of the secondary waste and cesium at a cost of $\$ 22$ million. Storage for 1,137 Phase I canisters would require $284 \mathrm{TN}-24$ casks at a cost of $\$ 284$ million.

\section{Facility Location}

A cask storage area of 3.6 ha could be located next to the Phase I Demonstration Plant. Adequate space is available at the site identified for the Demonstration Plant to accommodate a cask system storage area.

10. Estimated Cost

The cost of a standalone cask system varies greatly from system to system (Table 5-1). The least expensive system holding a single canister costs approximately $\$ 180,000$ per cask. The larger casks that hold five canisters cost up to $\$ 1,200,000$ per cask. These systems are for commercial spent nuclear fuel. The cost does not include any redesign or testing of the systems that may be required for them to hold HLW canisters. 
Table 5-1. Storage System Parameters for Phase I Canisters.

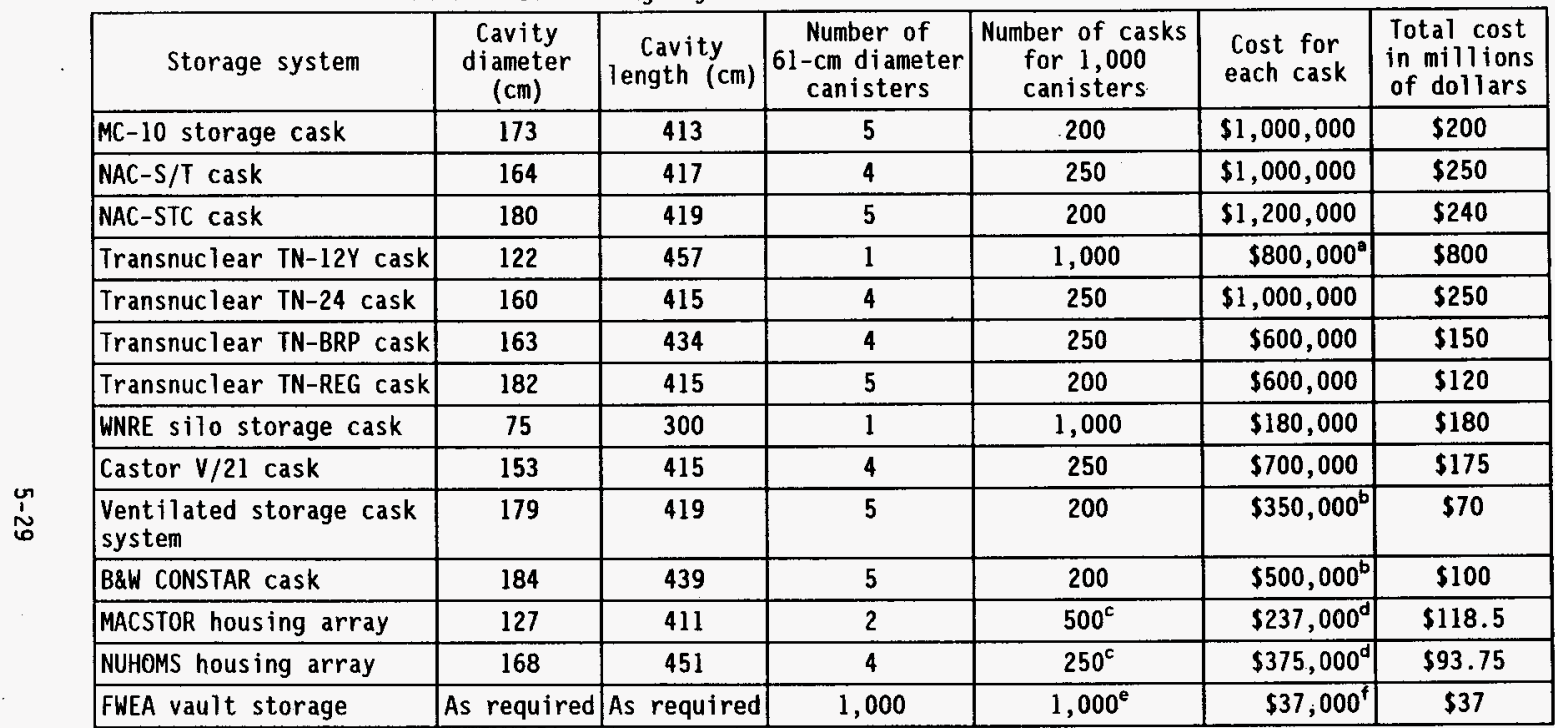

${ }^{\text {An }}$ average cost based on the cost range of $\$ 600,000$ to $\$ 1,000,000,000$ from WHC-SD-CP-ES-155 (WHC 1994 ).

Based on the higher cask cost given in WHC-SD-CP-ES-155 (WHC 1994).

Number of modules for 1,000 canisters.

dost for each module.

Number of storage tubes for 1,000 canisters.

${ }^{6}$ Cost per storage tube.

$B \& W=$ Babcock \& Wilcox

FWEA $=$ Foster Wheeler Energy Corporation, Applications Division

WNRE = Whiteshe11 Nuclear Research Estabi ishment 
In addition to the cask cost is the cost for the cranes and vehicles to handle and transport the casks from the Phase $I$ plant to the storage facility and from the storage facility to the inspection/recovery facility. Additional cost also includes a separate facility to transfer the canisters from the transport cask to the inner container. The container would be welded shut in this facility and loaded into the transport cask for transfer to the storage pad. This facility could also be designed with the capability to retrieve failed canisters.

\section{Additional Considerations}

If a standalone cask were chosen, the U.S. Nuclear Regulatory Commission CoC would have to be reviewed to ensure that the seismic criteria used for the license meets the Hanford Site standards.

\section{Recommendation}

A standalone cask system is not the recommended option for Phase I or Phase II storage. The cost of the casks, transportation equipment, and a facility to load/unload and examine canisters is higher than other options.

\subsubsection{Housing Arrays}

The typical housing array consists of a semishielded inner container with basket, a shielded transfer overpack-cask, and the storage structure. The basket inside the container is designed to hold the Phase I glass canisters in a safe configuration. The canister spacing inside the container determines the number of storage modules required to store the Phase I glass. The glass canisters are loaded into the inner container and placed into the transfer cask. The combination is then transported to the site of the storage structure where the container is pushed through the transfer overpack-cask and inserted into the storage structure.

The housing array systems are similar to the standalone cask system in that the HLW canisters must be loaded into an inner container. The inner container is partitioned to hold as many canisters as the cavity of the cask allows and has a sealable lid that provides secondary confinement. The container is then $\mathrm{placed}$ into a transport cask or the storage cask for transfer to the storage pad. The Demonstration Plant scope contains the requirement to place the canister into a transport cask. The housing array system requires the additional step of placing the canisters into a container and sealing the container. This requirement will have to be added to the scope of the Demonstration Plant or a facility will have to be built to transfer the canister from one transport cask to the inner container and then to a new transport cask.

Two housing array systems are available: NUHOMS* and the modular aircooled canister storage (MACSTOR) system. The NUHOMS system uses an inner

"NUHOMS is a trademark of Vectra Technologies, Inc. 
container called a dry shielded canister (DSC). Shielding is located at the top and bottom of the DSC and is designed to supplement the shielding of the storage structure, which is called the horizontal storage module (HSM). The DSC cavity diameter is $168 \mathrm{~cm}$ and its wall thickness is $1.59 \mathrm{~cm}$.

Two different DSC cavity lengths are available $(451$ and $424 \mathrm{~cm})$ to accommodate BWR and PWR fuel, respectively. For transport, the DSC is placed inside the transfer cask which provides sidewall shielding. The transfer cask includes carbon steel and lead walls, neutron- shielding resin, cooling fins, and an outside jacket of stainless steel. Its maximum loaded weight is $113 \mathrm{MT}$. The HSM is a shielded, ventilated concrete structure placed on a concrete basemat. The HSM can provide a horizontal "single-in-line" configuration or a double "back-to-back" line configuration (Figure 5-8). The DSC is inserted horizontally into the HSM using transfer equipment (i.e., cask support skid, transporter trailer, and ramming apparatus [Figure 5-9]). The DSC is supported on rails which are attached to a steel support structure with the HSM (Figure 5-10). An HSM that holds a single container for PWR fuel measures $3 \mathrm{~m}$ wide by $5.5 \mathrm{~m}$ long.

The MACSTOR system uses an inner container called a fuel storage canister (FSC). It is a steel cylindrical shell with a cavity $127 \mathrm{~cm}$ in diameter by $411 \mathrm{~cm}$ long. The lid has sealable drain and vent openings, with leakage monitoring capability. The FSC has some shielding on the lid and bottom. Supplemental shielding is provided by the transfer cask during transport and the MACSTOR vault during storage. The transfer cask consists of steel and lead with neutron-shielding solid resin on the outside. This cask is loaded from the top, but it uses a thick steel bottom plug that is removed to allow the inner container (FSC) to be lowered into the MACSTOR storage module. A gantry crane is used to move the transfer cask from the transport trailer to the top of the storage module, where it is secured to a canister alignment fixture in a vertical position. A hydraulic jack on the gantry cask-handling trolley lowers the FSC into the module. The MACSTOR module is a reinforced concrete structure about 7.3 by $18.3 \mathrm{~m}$ that is designed to hold $20 \mathrm{FSCs}$. Wall thicknesses are determined by shielding analysis, and heat dissipation is accomplished by passive convective air flow. Weather protective covers are used above each canister storage location.

\section{Evaluation}

\section{Seismic}

The storage array systems that are commercially available have (onsitespecific) CoCs issued by the U.S. Nuclear Regulatory Commission. A CoC indicates that the cask complies with the requirements of 10 CFR 72 , "Licensing Requirements for the Independent Storage of Spent Nuclear Fuel and High-Level Radioactive Waste." Part 72 requires that seismic evaluations be conducted to ensure the safe storage of the waste.

2. State, Federal, and DOE Criteria for Waste Storage Facility

The storage array would be designed to meet all state, federal, and DOE criteria for a waste storage facility. 
WHC-SD-WM-ES-374

Revision 0

Figure 5-8. Illustration of Typical NUHOMS Storage Module Arrangement.

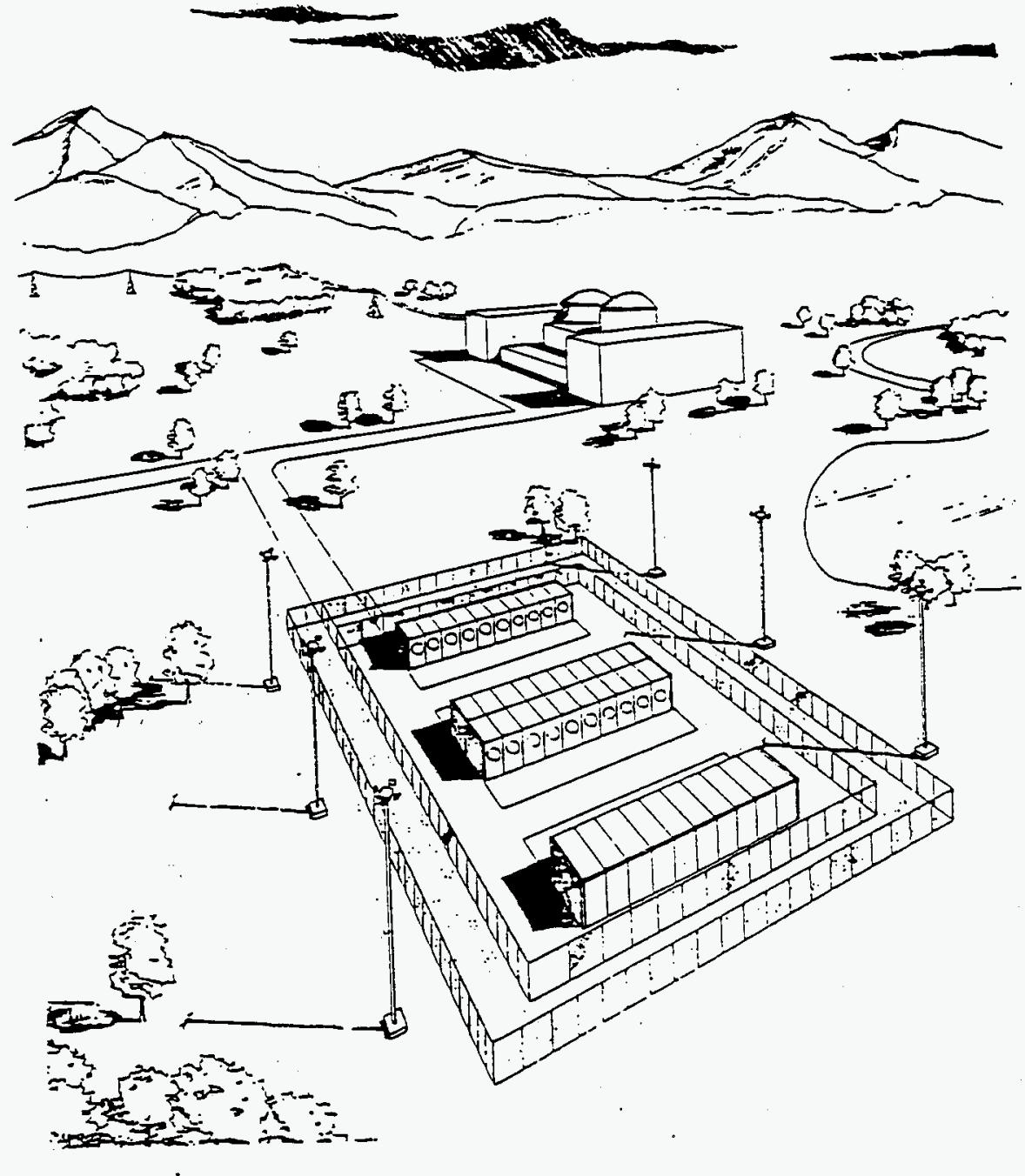


Figure 5-9. NUHOMS System Components, Structures, and Transfer Equipment.

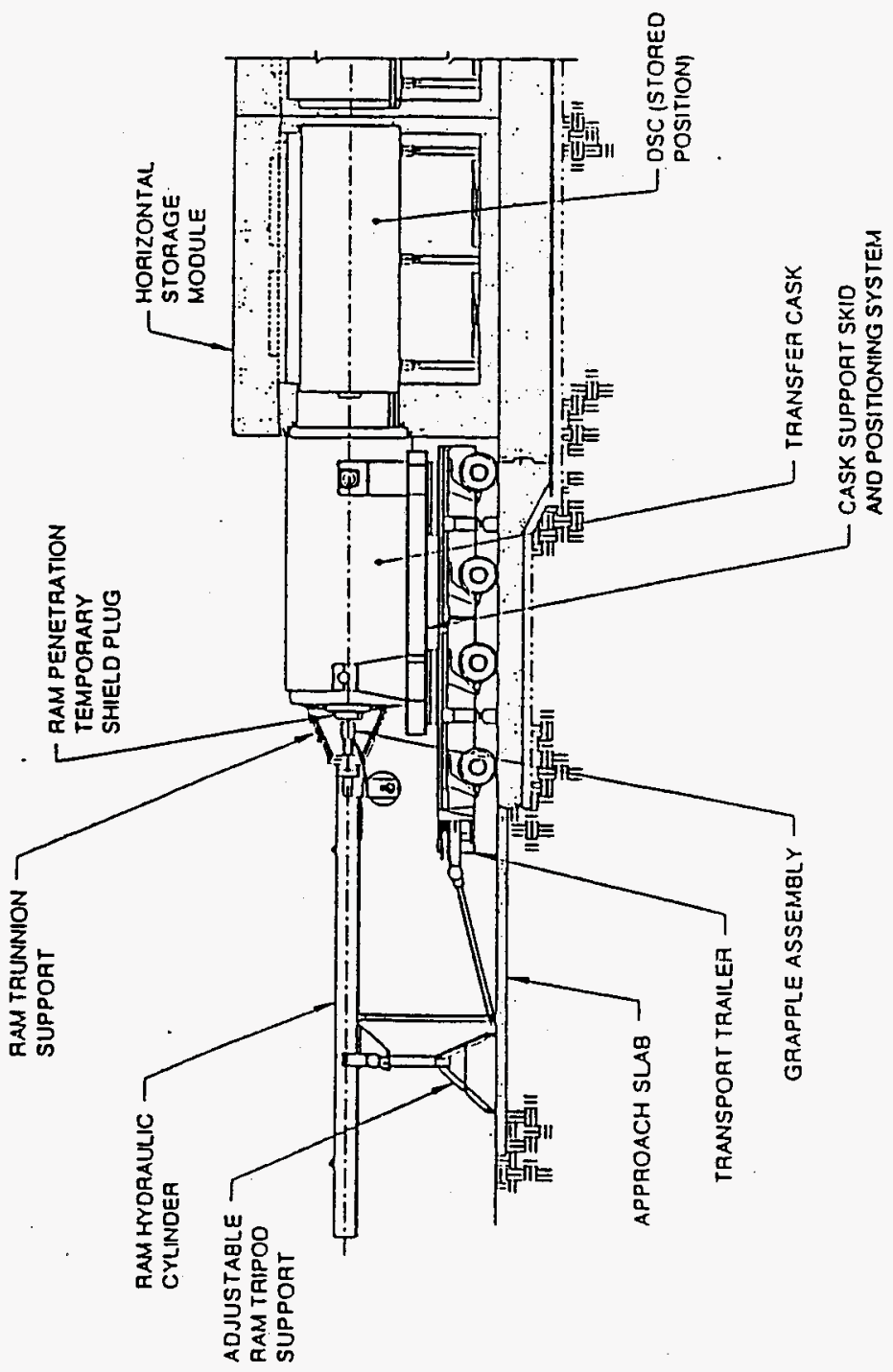


WHC-SD-WM-ES-374

Revision 0

Figure 5-10. NUHOMS Horizontal Storage Module Arrangement.

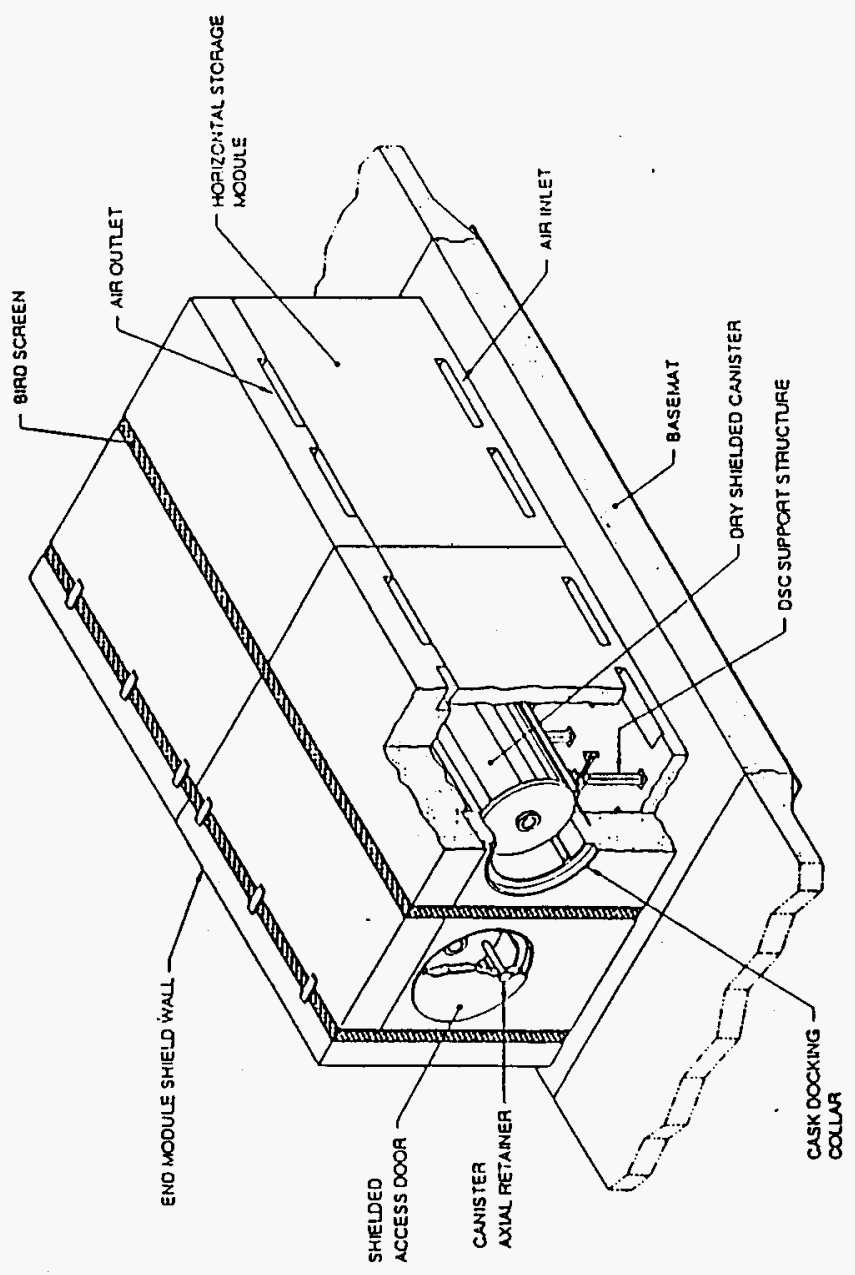


WHC-SD-WM-ES-374

Revision 0

3. Remote Handling

There is no remote handling required with this type of system because the canisters are inside a shielded transport cask or the storage structure. However, each of these systems requires special cask handling equipment to move the casks and place them into the storage structure.

4. Air Temperature and Contamination Monitoring

The storage array is designed to transfer heat to the ambient air without any mechanical systems. Each type of array has a limit to its heat transfer capabilities and the system chosen will have to be evaluated for this criterion. Primary confinement is provided by the inner containers which are sealed before being put into the cask. The storage array will have air monitoring devices to detect radiation.

5. Canister Inspection Capabilities

Canister inspection will require the removal of the inner container from the storage array and taking it to a facility where the container can be opened and inspected.

6. Failed Canister Detection and Recovery Capabilities

A failed canister cannot be detected unless the container in which it is stored also fails. A storage array system requires a facility in which to inspect and recover failed canisters. The inspection/recovery facility needs to remain operational for the lifetime of the storage facility.

\section{Facility Storage Capacity}

The MACSTOR container would hold two glass canisters each. Each MACSTOR module $(7.3$ by $18.3 \mathrm{~m}$ ) holds 20 containers. The MACSTOR system would require 25 modules for 1,000 Phase I canisters. The storage area for a MACSTOR system is $36,000 \mathrm{ft}^{2}$ or approximately 0.4 ha. The NUHOMS system can hold four glass canisters per container. Using a single container storage module requires 250 modules for storing 1,000 Phase I canisters. Assuming an area of $176 \mathrm{ft}^{2}$ per module, the storage area is $44,000 \mathrm{ft}^{2}$ or approximately 0.5 ha.

8. Facility Storage Capacity for Additional Secondary HLW

The secondary waste from Phase I could be included in either of these systems with a minimal impact to the size and cost of the facility.

9. Facility Location

A set of housing arrays 0.5 ha in size could be located next to the Phase I Demonstration Plant. 


\section{Estimated Cost}

The cost for the NUHOMS container (DSC) and the storage module (HSM) is estimated to be $\$ 250,000$ and $\$ 125,000$, respectively. This $\$ 375,000$ total cost does not include costs for transfer equipment (i.e., cranes, vehicles, transfer cask, skid, lifting yoke, ramming system, and positioning trailer). The cost for the MACSTOR storage system (the FSC and storage module) is estimated to be $\$ 237,000$. This does not include costs for the transfer cask, crane, alignment device, and trailer. See Table 5-1 for total costs.

\section{Recommendation}

A housing array system is not the recommended option for Phase I or Phase II storage. The cost of the casks, transportation equipment, and a facility to load/unload and examine canisters is higher than other options.

\subsubsection{Vault Storage}

Two vault storage systems are available that are appropriate for the HLW glass canisters: the CSB previously discussed and the Fort St. Vrain type (Figure 5-11). The Fort St. Vrain facility vault is similar to the CSB vault except that it is an aboveground modular vault designed for commercial fuel.

The Fort St. Vrain system requires the vitrified HLW glass canister to be loaded into a transfer cask inside the Demonstration Plant. The transfer cask is oriented in the horizontal position when it arrives in the storage facility. An overhead crane uprights the transfer cask in the reception/loadout bay. The canister is removed from the transport cask by a shielded canister handling machine. The canister handling machine then traverses the storage modules to a storage tube and inserts the canister into the tube. A seal plug is then placed into the tube.

In 1988, the U.S. Nuclear Regulatory Commission approved a nonsitespecific topical safety analysis report (TSAR) for a modular dry storage vault designed by Foster Wheeler Energy Corporation, Applications Division (FWEA). This TSAR was used as a basis for a site-specific license for a storage vault at Fort St. Vrain. The FWEA design contains all the canister monitoring, retrieval, and inspection capabilities required for the storage facility, based on a storage tube size of $30.5 \mathrm{~cm}$. This storage tube design is too small for the Phase I glass canisters and would require resizing. A new facility based on the Fort St. Vrain facility could be designed to meet all state, federal, and DOE criteria.

\section{Evaluation}

1. Seismic

The vault of a Fort St. Vrain-type facility is a Safety Class 1 structure. The facility would have safety class electrical, instrument, and control systems. 
Figure 5-11. Single MVDS Vault Module.

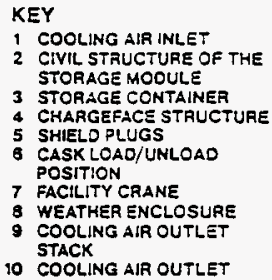

1 COOLING AIR INLET

2 CIVIL STRUCTURE OF THE STORAGE MODULE

3 STOAAGE CONTAINEA

4 CHARGEFACE STRUCTUAE

5 SHIELO PLUGS

- CASK LOAD/UNLOAD POSITION

7 FACILITY CRANE

8 WEATHER ENCLOSURE

- cooling aIR OUTLET STACK

10 COOLING AIR OUTLET

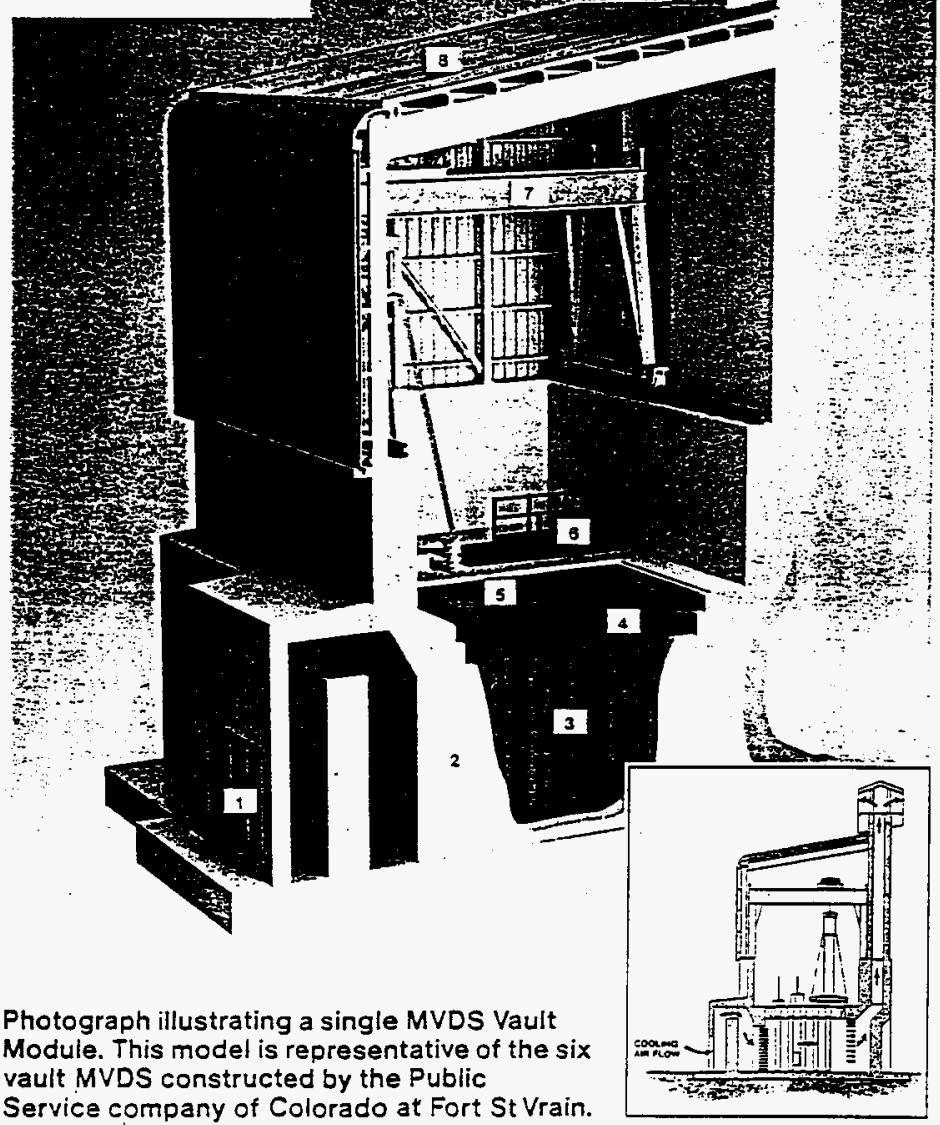


2. State, Federal, and DOE Criteria for Waste Storage Facility

The facility would be designed to meet all the current requirements for nuclear waste storage facilities.

3. Remote Handling

The facility would have the capability to remotely handle the canisters using the shielded canister handling machine.

4. Air Temperature and Contamination Monitoring

The storage vaults are designed for passive cooling. Outside air enters one side of a vault and exits through a stack on the side (Figure 5-12). This design eliminates the need for a mechanical cooling system. The exhaust stack for each vault is monitored for contamination in the exhaust air.

5. Canister Inspection Capabilities

The storage vault facility would have an inspection station for inspecting and repackaging canisters.

6. Failed Canister Detection and Recovery Capabilities

The storage vault facility would be capable of detecting and retrieving failed canisters.

7. Phase I Storage Capacity

The Fort St. Vrain facility has a footprint of 21.3 by $46.3 \mathrm{~m}, 0.1 \mathrm{ha}$, based on 270 storage tubes with a $76.2-\mathrm{cm}$ pitch (distance between tube centers). A Phase I storage facility requires more than 1,000 larger diameter storage tubes at a larger pitch. The secondary HLW and cesium canisters would not have a significant impact on the size of the facility. It is assumed that a facility for Phase I would be in the range of 1 ha.

8. Facility Location

A fort St. Vrain-type facility covering 1 ha could be built adjacent to the Phase I Demonstration Plant.

9. Estimated Cost

The estimated cost for the Fort St. Vrain-type facility is based on $\$ 20,000$ per storage location, and does not include costs for transportation casks and a canister handling machine. Increasing the storage tube size would tend to increase the overall facility cost. other estimates for similar facilities range up to $\$ 37,000$ per storage location. See Table 5-1 for total costs. 
WHC-SD-WM-ES-374

Revision 0

Figure 5-12. MVDS Natural Convection Cooling - Vault Cross-Section.
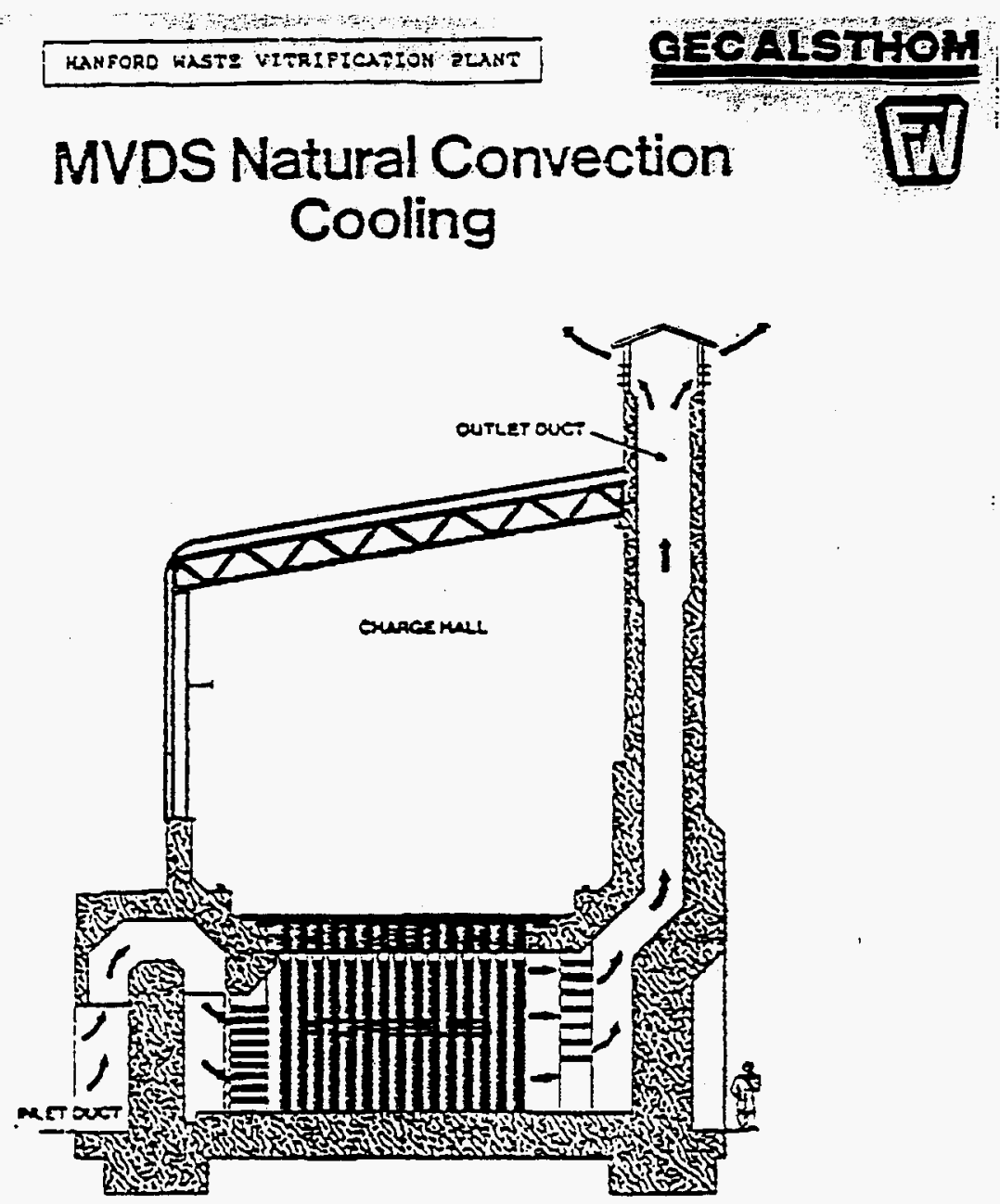
WHC-SD-WM-ES-374

Revision 0

\section{Recommendation}

As previously recommended, modifying the CSB is the preferred option for Phase I. A new vault storage facility is a viable option for Phase II storage. The CSB design would be the preferred design because it more closely matches the requirements of the HLW canisters, e.g., tube size, shielding.

\subsection{OFFSITE}

An offsite storage location was not considered because there is currently no known location that will accept this type of waste.

\subsection{PHASE II STORAGE}

The criteria for a facility to interim store the glass canisters for the Phase II vitrification facility are the same as for the Phase I plant except for the quantity and size of the canisters. The number of canisters estimated for Phase II ranges from 6,000 to 20,000. Using the higher range estimate to evaluate the alternatives eliminates all of them except the standalone cask, housing array, and the vault storage. These systems all have the advantage of being modular. They can be designed for the lower end of the range of canisters and then expanded as required. The cost of these alternatives is shown in Table 5-2.

The site proposed for the Phase II complex (Area 4 in Figure 3-1) includes 7.28 ha for HLW storage. The housing array and vault storage option could provide storage for 20,000 canisters in that area. The standalone cask system requires approximately 16.2 ha to store 20,000 canisters using a $20-\mathrm{ft}^{2}$ area per canister. If this option is chosen, the Phase II facility layout as shown in WHC-SD-WM-SD-023 (Shord 1996) will have to be reevaluated. 
Table 5-2. Storage System Parameters for Phase II Canisters.

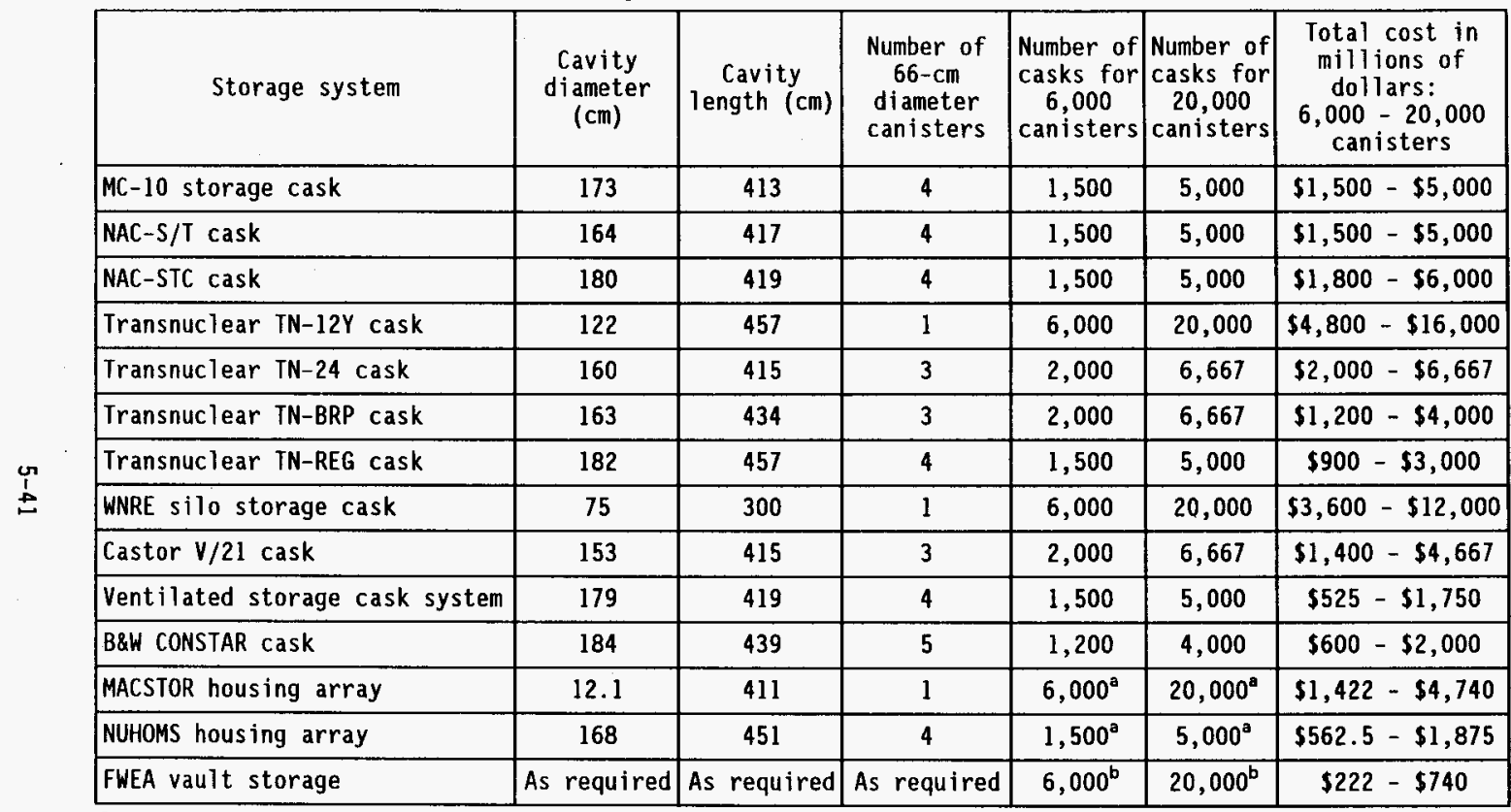

Number of modules for 6,000 or 20,000 canisters.

Number of storage tubes for 6,000 or 20,000 canisters.

$B \& W=$ Babcock \& Wilcox

FWEA = Foster Wheeler Energy Corporation, Applications Division

WNRE = Whiteshell Nuclear Research Establishment 
WHC-SD-WM-ES-374

Revision 0

This page intentionally left blank. 
WHC-SD-WM-ES-374

Revision 0

\subsection{SUMHARY}

A summary of the alternatives' compliance with the design criteria for Phase I is presented in Table 6-1.

Based on the results discussed in Section 5.0, the CSB would be the best option for the interim storage of the Phase I canisters. Phase I would require approximately two vaults of the current CSB. The cost to modify the two vaults for Phase I is lower than all the other alternatives. The CSB also could be expanded to have an additional three vaults added on to the existing facility. This would provide added capacity if the Phase I campaign is extended.

The Phase II vitrified HLW and secondary waste will require a new storage facility unless the 200 Area siting criteria are changed. There are no existing facilities on the 200 Area Plateau that meet the requirements for Safety Class 2 structures and storage capacity. The Spray Pond option is the lowest cost alternative. The WNP Spray Ponds meet the Safety Class 2 requirement and together they provide sufficient storage space for all the Phase II canisters; however, they are not located on the 200 Area Plateau. The vault storage option is the next lowest cost alternative that meets all the criteria, including location. 
Table 6-1. Compliance with Design Criteria.

\begin{tabular}{|c|c|c|c|c|c|c|c|c|}
\hline \multirow[b]{2}{*}{ Criteria } & \multicolumn{8}{|c|}{ Alternatives } \\
\hline & $\begin{array}{l}\text { B, T, U } \\
\text { Plants }\end{array}$ & $\begin{array}{l}\text { PUREX } \\
202-A\end{array}$ & FMEF & WNP-4 & CSB & $\begin{array}{c}\text { Standalone } \\
\text { cask }\end{array}$ & $\begin{array}{l}\text { Housing } \\
\text { arrays }\end{array}$ & $\begin{array}{l}\text { Vault } \\
\text { storage }\end{array}$ \\
\hline Seismic qualifications & Yes $^{\mathrm{a}}$ & Yes $^{a}$ & Yes $^{a}$ & Yes $^{a}$ & Yes & Yes & Yes & Yes \\
\hline Phase I storage capacity & Yes $^{b}$ & Yes $^{b}$ & Yes & Yes $^{b}$ & Yes $^{a}$ & Yes & Yes & Yes \\
\hline $\begin{array}{l}\text { Storage capacity for secondary } \\
\text { waste and cesium }\end{array}$ & Yes $^{b}$ & Yes $^{b}$ & Yes & Yes $^{b}$ & Yes $^{a}$ & Yes & Yes & Yes \\
\hline Remote handling & Yes $^{b}$ & Yes $^{b}$ & Yes $^{b}$ & Yes $^{b}$ & Yes & N/A & N/A & Yes \\
\hline $\begin{array}{l}\text { Detection and recovery of failed } \\
\text { canister }\end{array}$ & Yes $^{b}$ & Yes $^{b}$ & Yes $^{b}$ & Yes $^{b}$ & Yes & No & No & Yes \\
\hline Canister retrieval and inspection & Yes $^{b}$ & Yes $^{b}$ & Yes $^{b}$ & Yes $^{\mathrm{b}}$ & Yes & No & No & Yes \\
\hline Cost (1996 dollars) & $\$ 28.5 \mathrm{M}$ & $\$ 24.8 \mathrm{M}$ & d & $\$ 271 \mathrm{M}$ & $\$ 22 \mathrm{M}$ & $\begin{array}{c}\text { See } \\
\text { Table 5-1 }\end{array}$ & $\begin{array}{c}\text { See } \\
\text { Table 5-1 }\end{array}$ & $\begin{array}{c}\text { See } \\
\text { Table 5-1 }\end{array}$ \\
\hline
\end{tabular}

Will require additional analysis as facility is modified.

Will require extensive modifications to existing facility.

Natural convection cooling.

No previous cost estimates for modification of the FMEF were found.

CSB = Canister Storage Building

FMEF = Fuels and Materials Examination Facility

$N / A=$ Not available

PUREX = Plutonium-Uranium Extraction

WNP-1 = Washington Nuclear Plant-1 
WHC-SD-WM-ES-374

Revision 0

\subsection{REFERENCES}

10 CFR 72, "Licensing Requirements for the Independent Storage of Spent Nuclear Fuel and High-level Radioactive Waste," Code of Federal Regulations, as amended.

Carlson, A. B., 1995, Solid Waste and Materials System Alternatives Study, WHC-SD-WM-ES-341, Rev. 0, Vols. 1 and 2, Westinghouse Hanford Company, Richland, Washington.

Drummond, M. E., 1992, The Future of Hanford: Uses and Cleanup--The Final Report of the Future Site Uses Working Group, Chaired by M. E. Drummond, President of Eastern Washington University, Cheney, Washington.

Fluor, 1996, HLW Interim Storage Facility Feasibility Study, Fluor Daniel, Inc., Richland, Washington.

Kaiser, 1990, Hanford Waste Vitrification Plant Project Interim Storage Facility for Hanford Waste Vitrification Plant Canisters Evaluation of Alternatives, Work Order ER0665, Kaiser Engineers Hanford, Richland, Washington.

Kalia, J., 1992, Hanford Waste Vitrification Plant Project Functional Design Criteria, WHC-SD-HWV-FDC-001, Rev. 5, Westinghouse Hanford Company, Richland, Washington.

Monthey, M. J., 1994, Commercially Available Dry Storage Systems for Storage of Irradiated Fuel on the Hanford Site, WHC-SD-CP-ES-155, Rev. 0 , Westinghouse Hanford Company, Richland, Washington.

Murkowski, R. J., 1989, B Plant Canyon Structure Seismic Evaluation, WHC-SD-WM-SA-005, Rev. 0, Westinghouse Hanford Company, Richland, Washington.

RL, 1996, TWRS Privatization Request for Proposals, Solicitation Number DE-RP06-96RL13308, U.S. Department of Energy, Richland Operations office, Richland, Washington.

Shord, A. L., 1996, Tank Waste Remediation System Privatization Phase I Evaluation Report, WHC-SD-WM-SD-023, Rev. 0-A, Westinghouse Hanford Company, Richland, Washington.

WHC, 1993, Existing Alternate Storage Locations for N-Reactor Fuel at Hanford, WHC-SD-NR-ES-010, Rev. 0, Westinghouse Hanford Company, Richland, Washington. 
WHC-SD-WM-ES-374

Revision 0

This page intentionally left blank. 
WHC-SD-WM-ES-374

Revision 0

\subsection{BIBLIOGRAPHY}

10 CFR 71, "Additional Requirements for Type B Packages," Code of Federa 7 Regulations, as amended.

Calmus, R. B., 1995, Definition Canister Storage Building Feasibility Study Work Scope Secondary HLW and Large Canisters (DSI Memorandum to E. R. Jacobs, Fluor Daniel, Inc., December 27), Westinghouse Hanford Company, Richland, Washington.

Stegen, G. E., 1995, Estimated Phase I Glass Production (DSI Memorandum to R. Carreon, U.S. Department of Energy, Richland Operations Office, October 5), Westinghouse Hanford Company, Richland, Washington. 
WHC-SD-WM-ES-374

Revision 0

This page intentionally left blank. 


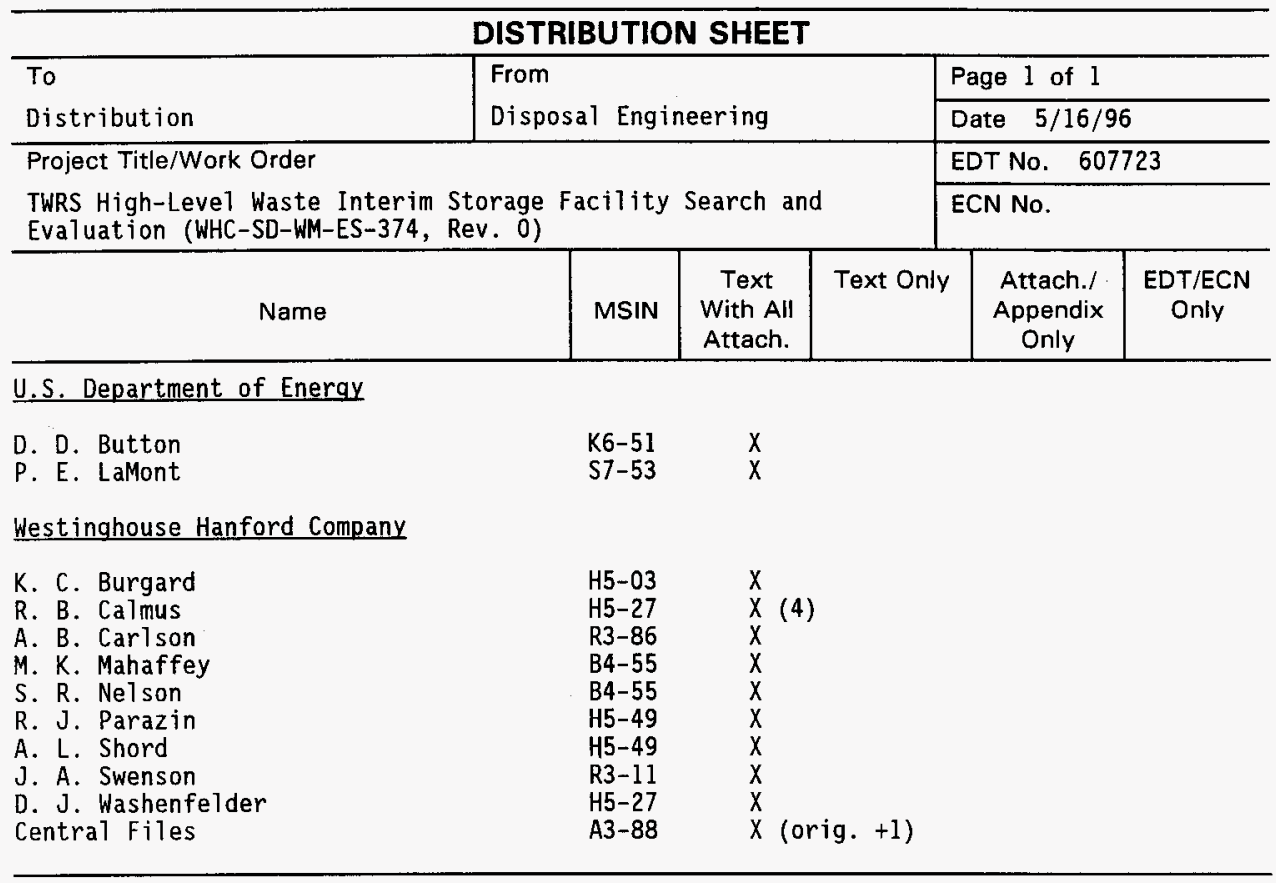

